\title{
Modelling Saharan dust transport into the Mediterranean basin with CMAQ
}

\author{
David de la Paz ${ }^{a}$, Michel Vedrenne ${ }^{a}$, Rafael Borge ${ }^{a, *}$, Julio Lumbreras ${ }^{a}$, \\ Juan Manuel de Andrés ${ }^{a}$, Javier Pérez ${ }^{a}$, Encarnación Rodríguez ${ }^{a}$, \\ Angeliki Karanasiou $^{b}$, Teresa Moreno ${ }^{b}$, Elena Boldo ${ }^{c, d}$, Cristina Linares ${ }^{c, d}$ \\ ${ }^{a}$ Department of Chemical \& Environmental Engineering. Technical University of Madrid, (UPM), c/José Gutiérrez Abascal 2, 28006 Madrid, Spain \\ bInstitute of Environmental Assessment and Water Research (IDAEA), Spanish Research Council (CSIC), c/Jordi Girona 18-26, 08034 Barcelona, Spain \\ ${ }^{\mathrm{C}}$ Cancer and Environmental Epidemiology Unit, National Center for Epidemiology, Carlos III Institute of Health, Avda. Monforte de Lemos, 5 , \\ 28029 Madrid, Spain \\ ${ }^{d}$ CIBER en Epidemiología y Salud Pública (CIBERESP), Spain
}

\section{H I G H L I G H T S}

- A dust emission module has been implemented in the WRF-SMOKE-CMAQ modelling system.

- The system has been applied and evaluated for Saharan dust outbreaks into Europe.

- Contributions up to $14 \mu \mathrm{g} \mathrm{m}^{-3}$ to $24-\mathrm{h} \mathrm{PM}_{10}$ concentration were predicted in Spain.

- Global $R$-value for ground-level $\mathrm{PM}_{10}$ increased from 0.33 to 0.48 .

- Good agreement with satellite products although AOD is underestimated.

\begin{abstract}
A B S T R A C T
The need for a better quantification of the influence of Saharan dust transport processes on the air quality modelling in the Mediterranean basin led to the formulation of a dust emission module (DEM) integrated into the Air Quality Risk Assessment System for the Iberian Peninsula (SERCA). This paper is focused on the formulation of DEM based on the GOCART aerosol model, along with its integration and execution into the air quality model. It also addresses the testing of the module and its evaluation by contrasting results against satellite products such as MODIS and CALIPSO and ground-level observations of aerosol optical thickness (AOT) and concentration levels of $\mathrm{PM}_{10}$ for different periods in july 2007. DEM was found capable of reproducing the spatial (horizontal and vertical) and temporal profiles of Saharan dust outbreaks into the Mediterranean basin and the Atlantic coast of Africa. Moreover, it was observed that its combination with $\mathrm{CMAQ}$ increased the correlation degree between observed and modelled $\mathrm{PM}_{10}$ concentrations at the selected monitoring locations. DEM also enhanced CMAQ capabilities to reproduce observed AOT, although significant underestimations remain. The implementation of CMAQ + DEM succeeded in capturing Saharan dust transport into the Iberian Peninsula, with contributions up to 25 and $14 \mu \mathrm{g} \mathrm{m}^{-3}$ in $1 \mathrm{~h}$ and $24 \mathrm{~h}$ average $\mathrm{PM}_{10}$ respectively. The general improvement of total $\mathrm{PM}_{10}$ predictions in Spain are however moderate. The analysis of model performance for the main PM components points out that remaining $\mathrm{PM}_{10}$ underestimation is due to dust local sources missing in the inventories and misrepresentation of organic aerosol processes, which constitutes the main areas for future improvement of CMAQ capabilities to simulate particulate matter within SERCA.
\end{abstract}

Abbreviations: AERONET, Aerosol Robotic Network; AOD, Aerosol Optical Depth; AOT, Aerosol Optical Thickness; AQM, Air Quality Model; CALIPSO, Cloud Aerosol Lidar

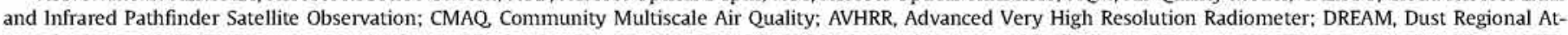

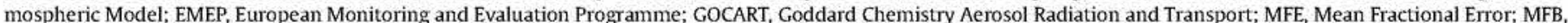

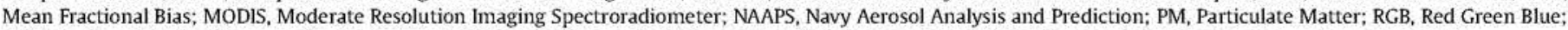
SMOKE, Sparse Matrix Operator Kernel Emissions; TAB, Total Attenuated Backscatter; UTC, Universal Time Coordinated; WRF, Weather Research and Forecasting.

* Corresponding author. Tel.: +34 913363203; fax: + 34913363009.

E-mail address: rborge@etsii.upm.es (R. Borge). 


\section{Introduction}

Mineral dust interacts with climate and ecosystems in several important ways. Dust exerts a considerable influence on the atmosphere-earth system radiative balance, with an evident effect in the absorption and scattering processes of radiation, in the alteration of the optical properties of clouds and snow/ice surfaces and in the decrease of the photolysis rates of gases (IPCC, 2007; Shao et al., 2011). Additionally, the contribution of dust to the air pollution levels is directly related to increases in daily hospital admissions and clinic visits (Onishi et al., 2012).

The Mediterranean Basin is one of the most sensitive zones in the planet to air pollution, due to its high exposure to the anthropogenic emissions produced by the heavily industrialized European countries, the presence of megacities (Istanbul, Cairo, Athens, etc.) and dense maritime transport traffic. In addition to anthropogenic emissions, natural sources such as the Saharan dust transport, high sea-spray loads and frequent forest fires exert considerable stress on the regional air quality levels (Kanakidou et al., 2011).

Around $60 \%$ of the world's annual natural dust emissions $\left(2 \times 10^{9}\right.$ tons) are generated in the Sahara desert (Shao et al., 2011). Its proximity to the Mediterranean Basin and the typical circulation patterns of air masses are the main causes for the region to be the zone most exposed to mineral dust in the world (D'Almeida, 1986; Hatzianastassiou et al., 2009). Moreover, the region's climatic conditions such as scarce rains and summer droughts enhance the persistence of atmospheric aerosols, making the background particle levels higher than in the rest of Europe. For instance, dust outbreaks are responsible for $70 \%$ of the $\mathrm{PM}_{10}$ levels exceedances at regional background monitoring sites in the Mediterranean basin (Escudero et al., 2007; Mitsakou et al., 2008; Querol et al., 2009). Therefore it is important to incorporate this process into air quality modelling systems intended for air quality planning and assessment such as the Air Quality Risk Assessment System for the Iberian Peninsula (SERCA), intended to assess impacts on human health (Boldo et al., 2011) and ecosystems (de Andrés et al., 2012).

Addressing the problem of accurately quantifying the contribution of natural dust to the overall air quality levels, along with their temporal and spatial patterns is not an easy task. Essentially, the atmospheric lifetime of dust particles is very short, while dust outbreaks and their spatial profiles are strongly dependent on meteorological conditions. Moreover, the diffuse character of the emission sources, which determines the transport and distribution patterns of such dust episodes, renders the phenomenon even more complex to fully characterize. However, noticeable advances have been experienced in the compilation of natural dust inventories since satellite aerosol products became available in the late 90 s (Monks et al., 2009).

Despite such improvements, the accurate simulation of PM by $\mathrm{AQM}$ is still challenging due to the high uncertainty level associated to particle emissions, resuspension processes and the inherent complexity of aerosol chemistry. At the current state of knowledge of aerosol physics and chemistry and considering European anthropogenic emissions only, AQM still underestimate PM concentrations between 30 and $50 \%$ (Vautard et al., 2005). Consequently, several commendable efforts have been made to improve the reliability of PM level estimates in ambient air through the inclusion of modules in AQM that intend to describe the atmospheric dust dynamics more accurately. Examples of such improvements are the modules integrated into the DREAM (Pérez et al., 2006) or the CHIMERE-Dust module (Menut et al., 2009). Further efforts have been devoted to the development of forecasting systems like the SKIRON forecasting system of the University of Athens (Kallos et al., 2007) or the Navy Aerosol Analysis and Prediction System (NAAPS) of the Navy Research Laboratory (NRL, 2010).
This work presents the implementation and testing of a mineral dust emission model (hereinafter "DEM") linked to the WRFSMOKE-CMAQ modelling system (Borge et al., 2008a,b; Borge et al., 2010) which constitutes the basis of SERCA. To this respect, the version of CMAQ used for this study (CMAQ 4.6) is not able to treat dust emissions. Due to the strong influence that Saharan dust transport exerts on the Mediterranean air quality levels of the, and more concretely of Spain, a windblown dust model has been modelled for the region's particular conditions. The objective of this new module is to enhance CMAQ performance when assessing the contribution of mineral dust to the PM levels in the Mediterranean, leading to a better agreement between modelled and observed PM levels.

\section{Methodology}

\subsection{Description of the modelled domain}

The Mediterranean Basin is the region of interest modelled in this work, along with the surrounding Sahara and Sahel deserts. To this effect, a domain consisting of $124 \times 108$ cells with a $48 \mathrm{~km}$ resolution, centred at $34^{\circ} 20^{\prime} \mathrm{N}, 9^{\circ} 18^{\prime} \mathrm{E}$, has been used in order to capture synoptic features and general circulation patterns and to cover the arid regions of North Africa and the Canary Islands (Fig. 1). The modelled domain is an adaptation of the European domain considered in SERCA project, which was displaced $1815 \mathrm{~km}$ southwards and $375 \mathrm{~km}$ westwards. The model's vertical structure includes 30 layers covering the whole troposphere.

\subsection{Modelling system and setup}

The modelling system consists of the WRF meteorological model (Skamarock and Klemp, 2008), the SMOKE processing system (Institute for the Environment, 2009) and the CMAQ chemical transport model (Byun and Ching, 1999; Byun and Schere, 2006). The adaptation of SMOKE and WRF to European conditions, as well as their initialization and optimal setup for the Iberian Peninsula are described elsewhere (Borge et al., 2008a,b). CMAQ options and setup are discussed in Borge et al. (2010).

Emissions for Spain and Portugal were drawn from the 2007 editions of the National Atmospheric Emission Inventories of the Spanish Ministry for the Environment and the Portuguese Environmental Agency (MMA, 2010; APA, 2010). For the rest of the countries, as well as for international shipping, anthropogenic emission datasets were obtained from EMEP-gridded estimates (Vestreng, 2003). Biogenic VOCs were computed from the Global Emission Inventory Activity (GEIA).

\subsection{Episode selection}

It is well known that the synoptic Saharan dust patterns during summer are a consequence of the presence of high-pressure centres over Algeria and the Azores, as well as of another low-pressure centre that approaches from the Northwest in late July (Rodríguez et al., 2001; Escudero et al., 2005). Simulations were conducted for the entire month of July 2007. paying special attention to the following periods: 08 July $00 \mathrm{~h}$ UTC to 09 July $00 \mathrm{~h}$ UTC, 16 July $00 \mathrm{~h}$ UTC to 17 July $00 \mathrm{~h}$ and 30 july $00 \mathrm{~h}$ UTC to 31 July $00 \mathrm{~h}$ UTC. These time intervals correspond to dates where the Spanish Ministry for the Environment registered Saharan dust outbreaks during 2007 into the Iberian Peninsula and the Canary Islands (MMA-CSIC, 2007). Additionally, these dates matched the dust outbreak episodes forecasted by the NAAPS, DREAMS and SKIRON models. 


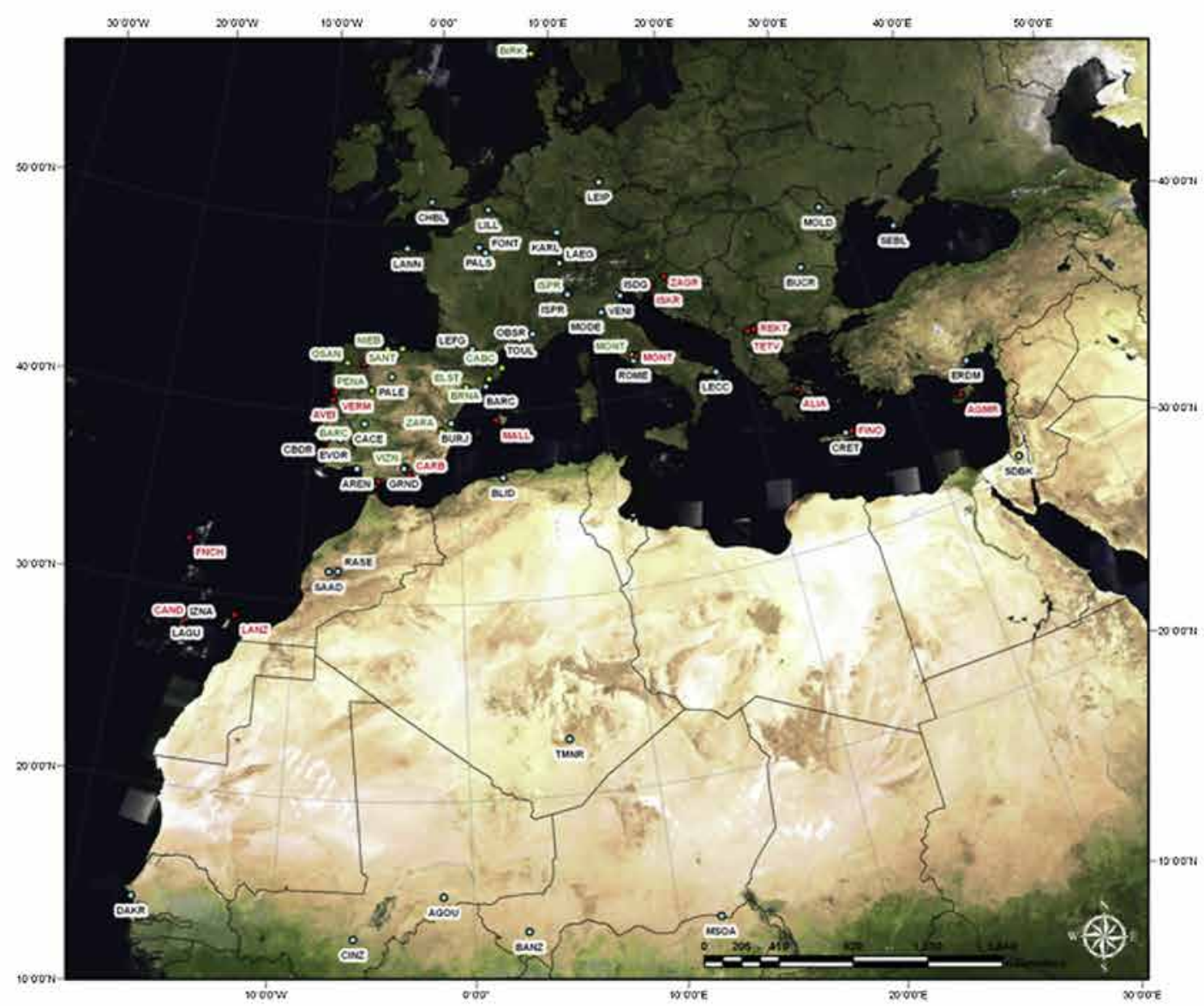

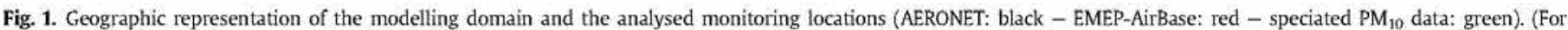
interpretation of the references to color in this figure legend, the reader is referred to the web version of this article.)

\subsection{Description of the natural dust emission module (DEM)}

Modelling the emissions of a natural windblown dust module under the framework of an atmospheric host model is a complex task, which implies the compatibility and reconciliation of the underlying atmospheric dynamics and physical processes and their parameterizations (Shao et al., 2011). Essentially, the design process of a dust emission model as a complement for an AQM involves two basic stages: (i) the establishment and definition of a dust emission scheme and (ii) the dust emission sources characterization. The first stage explains the mechanism through which dust is effectively emitted into the atmosphere and which will determine particle size distribution, while the second provides the location and size of the emission sources. The forecoming sections are devoted to the description of the formulation of DEM in terms of such stages.

\subsubsection{Dust emission sources}

The implemented dust sources' spatial distribution follows the same scheme than the GOCART model (Chin et al., 2000), which was further modified by (Ginoux et al., 2001) to include mineral dust. The mapping and description of such sources were obtained from the Dust Source Inventory of the NOAA's Geophysical Fluid Dynamics Laboratory (http://www.gfdl.noaa.gov). These data are based on the "topographic hypothesis" and its intersections with bare soil zones, identified with the AVHRR device and the TOMS Aerosol Index as described in Prospero et al. (2002). The assumed topographic approximation seems appropriate for this work since it has provided better correlation coefficients for the TOMS Aerosol Index for the Sahara desert than other hypotheses according to Zender et al. (2003). This approximation relies on a parameter called source function (S), which measures the availability of transportable dust at a given location. The obtained $\mathrm{S}$ data were further interpolated to the modelling grid described in Section 2.1 (Fig. 2).

\subsubsection{Dust emission scheme}

The dust emission scheme that DEM incorporates is the one described in Gillette and Passi (1988) and later modified by Ginoux et al. (2004). This scheme provides an equation for the estimation of the vertical flux of dust $(F)$ of an $F=\alpha\left(u-u_{\text {tp }}\right)$ type, which depends on an empirical coefficient $(\alpha)$, the friction velocity at $10 \mathrm{~m}(u)$ and the threshold friction velocity $\left(u_{\mathrm{tp}}\right)$. The general assumption is that the vertical flux of dust is proportional to the friction velocity $(u)$ provided that $u>u_{t}$. Additionally, Ginoux et al. (2001) defined the empirical coefficient $(\alpha)$ for every particle size class (p) (Eq. (1)).

$\alpha=C^{*} S^{*} s_{\mathrm{p}}{ }^{*} u^{2}$,

where $C=1 \mu \mathrm{g} \mathrm{s}^{2} \mathrm{~m}^{-5}, S$ is the source function and $s_{\mathrm{p}}$ is the mass fraction applied to each dust size class.

The threshold friction velocity for every particle size class (Eq. (1)) was estimated according to Marticorena and Bergametti (1995), which is a simplification of the equation developed by Iversen and White (1982). 


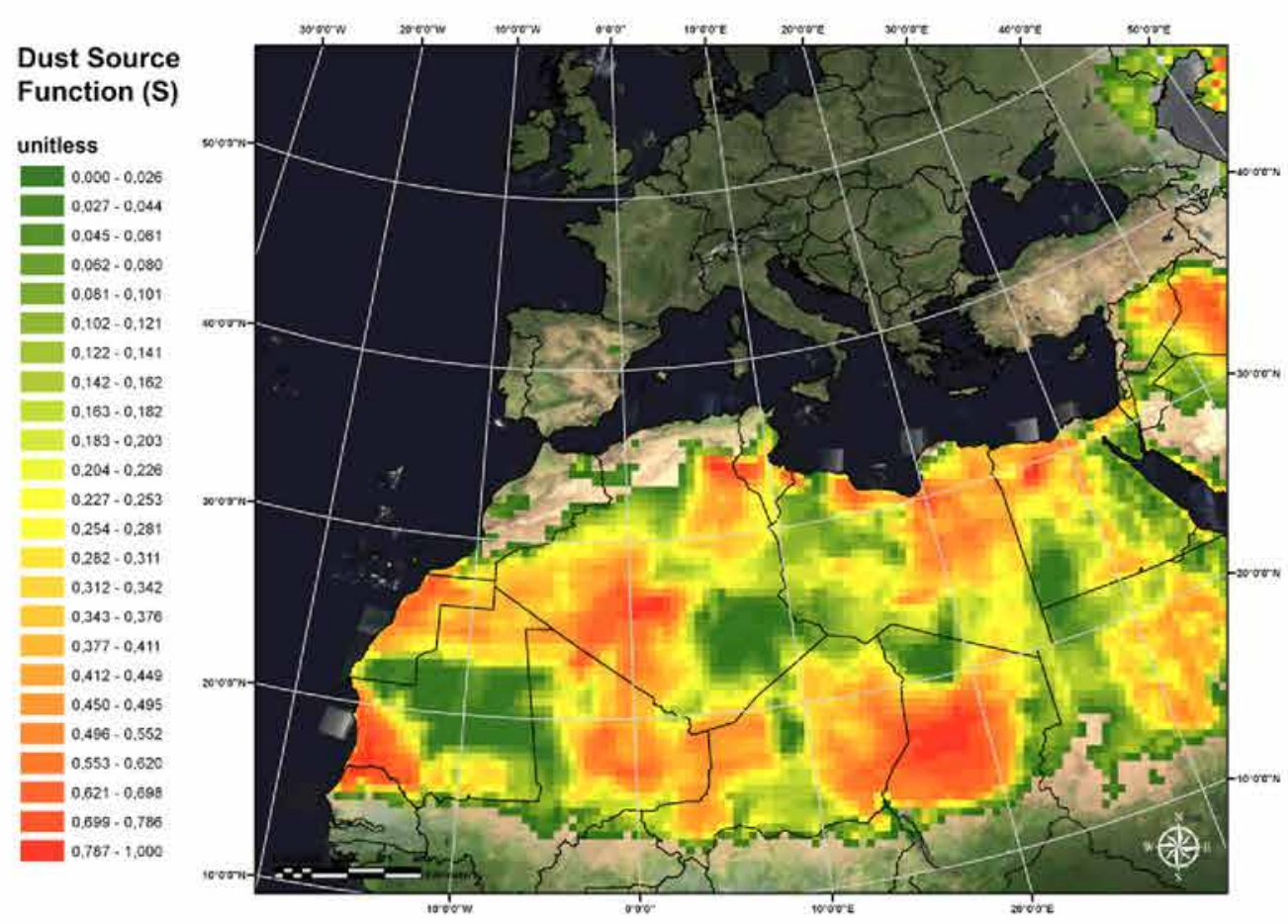

Fig. 2. Geographic distribution of the dust source function (S) according to Ginoux et al. (2001).

$u_{t, 0}=\frac{0.0013}{\sqrt{1.928\left(1331 \cdot D_{\mathrm{P}}^{1.56}+0.38\right)^{0.092}-1}} \cdot \sqrt{\frac{\rho_{\mathrm{P}} g D_{\mathrm{P}}}{\rho_{\mathrm{a}}}} \cdot \sqrt{1+\frac{0.006}{\rho_{\mathrm{P}} g D_{\mathrm{P}}^{2.5}}}$

where $D_{\mathrm{p}}$ is the particle class diameter, $\rho_{\mathrm{p}}$ is the particle class density, $\rho_{\mathrm{a}}$ is the air density. Ginoux et al. (2004) modified the threshold friction velocity estimated by Eq. (2) in order to include the effects of surface wetness $(w)$ according to Eq. (3):

$u_{t}= \begin{cases}u_{t, 0} \cdot\left(1.2+0.2 \log _{10} w\right) & \text { if } w<0.5 \\ \infty & \text { if } w \geq 0.5\end{cases}$

The size distribution of the atmospheric dust was obtained directly from Tegen and Fung (1994), which was in turn, elucidated from a series of empirical data.

\subsubsection{Module implementation}

DEM is integrated to the AQM following an off-line approach, which means that it can be executed individually and independently of the rest of the emissions. Nonetheless, outputs generated by DEM were combined with the outputs of SMOKE to form a single emissions input for CMAQ. Dust particles range from 0.1 to $10 \mu \mathrm{m}$ diameter and were grouped into 5 diameter class bins. This procedure does not require any additional format change, since DEM yields $1 / \mathrm{OAPI}$-compatible output files. Fig. 3 depicts the integration of DEM within the AQM general configuration.

\section{Model evaluation}

In order to assure that the estimates being provided by DEM are reasonable, it is essential to carry out a comparison between the model outputs and observations. Model estimates were compared with different types of observations from satellites and groundbased measurements.

\subsection{Satellite products}

The evaluation of air quality models with satellite products involves some uncertainty. In vertical profiles, deviations with model predictions may result from the presence of clouds, smoke, anthropogenic boundary layer aerosols, resolution issues or detection limits (Shaw, 2008). Nonetheless, they can provide valuable information on the general transport patterns, especially in the middle and upper troposphere. MODIS and CALIPSO data were retrieved to assess DEM capabilities in this study.

\subsubsection{MODIS}

The selected data from MODIS were RGB satellite images with a resolution of $500 \mathrm{~m}$ as well as $\mathrm{AOD}-0.55$-micron data obtained through the MOD04 Level Two Aerosol Product. These data are especially useful to assess the evolution of dust plumes and large dust emission sources. Specific information about the MODIS product is freely accessible (http://modis.gsfc.nasa.gov/).

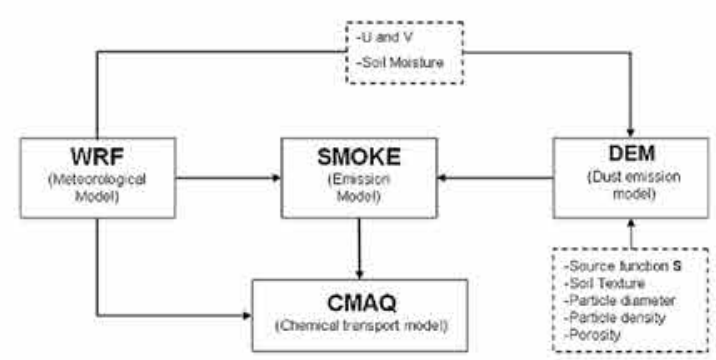

Fig. 3. General representation of the integration of DEM into the AQM. 


\subsubsection{CALIPSO}

Vertical TAB data were obtained from CALIPSO at a $532 \mathrm{~nm}$ wavelength for the selected episode dates and following the corresponding satellite routes. The pass times of CALIPSO over the modelled domain were July 8 , July 16 , July 30 . These profiles were used to evaluate whether the model is able to accurately reproduce the distribution of dust in the vertical direction. Further information on the CALIPSO product is available elsewhere (http://eosweb. larc.nasa.gov/).

\subsection{Ground-level observations}

\subsubsection{AERONET}

The AERONET consists of a worldwide network of sun photometers that measures the optical properties of aerosols (Holben et al., 1998). The data obtained from AERONET consisted in the daily average AOT level 2.0 at $440 \mathrm{~nm}$ (cloud-screened) for the entire month of July. Up to 44 monitoring sites were selected to assess the model performance. The geographic location of the selected monitoring sites is shown in Fig. 1 and described in detail in Table A.1.

\subsubsection{Air quality monitoring sites}

Ambient air concentrations of $\mathrm{PM}_{10}$ have been obtained from a series of monitoring locations belonging to either local (AirBase) or EMEP networks. The selected locations are reported in Table A.2 and shown in Fig. 1. From these stations, hourly $\mathrm{PM}_{10}$ concentration values for the month of July were obtained. Besides hourly resolved $\mathrm{PM}_{10}$ data, daily averages of $\mathrm{PM}_{10}$ major components were used to gain some understanding on the model's ability to represent the concentration of particulate matter and to provide a more precise view of the reasons for discrepancies between modelled and observed values. Speciated PM data from 11 EMEP monitoring stations and 3 monitoring campaigns (Table A.3) made by IDAEACSIC (Institute of Environmental Assessment and Water Research, Spanish Research Council) were used (Fig. 1). These field campaigns have been used with similar purposes in previous studies (Pay et al., 2012).

\subsection{Comparison of CMAQ outputs with MODIS and AERONET data}

It should be noted that the output obtained from CMAQ + DEM (PM) and MODIS/AERONET (AOT) are not directly comparable. Several studies have demonstrated that exists a linear relationship between both indexes ( $\mathrm{Li}$ et al., 2011) and therefore ground-level $\mathrm{PM}_{10}$ may constitute a good proxy for a qualitative analysis of model performance (Liu et al., 2005; Péré et al., 2009). Many authors have looked into possible ways to use satellite or ground-based vertical observations of the atmosphere to assess air quality models such as CMAQ in a more consistent way (Roy et al., 2007). Although remote sensing data may have important uncertainties, e.g. in the presence of clouds, during night time or over bright and highly reflective surfaces, such as desert regions (Torres et al., 2007), they provide a complementary view that may yield additional information on the capabilities of chemical transport models to represent vertical PM distribution patterns.

In order to establish a consistent comparison, aerosol optical thickness was computed from CMAQ outputs in particular locations. AOT values were derived from CMAQ outputs by vertically integrating scattering and absorption coefficients to estimate light extinction following the "reconstructed mass-extinction (RM) method" proposed by Binkowski and Roselle (2003). The scattering coefficients and the relative humidity aerosol growth factors for sulphates, ammonium and nitrates are taken from Malm et al. (1994). Sea salt has also been included in the computation of AOT. Hygroscopic growth factors for sea salt particles are taken from Park et al. (2011).
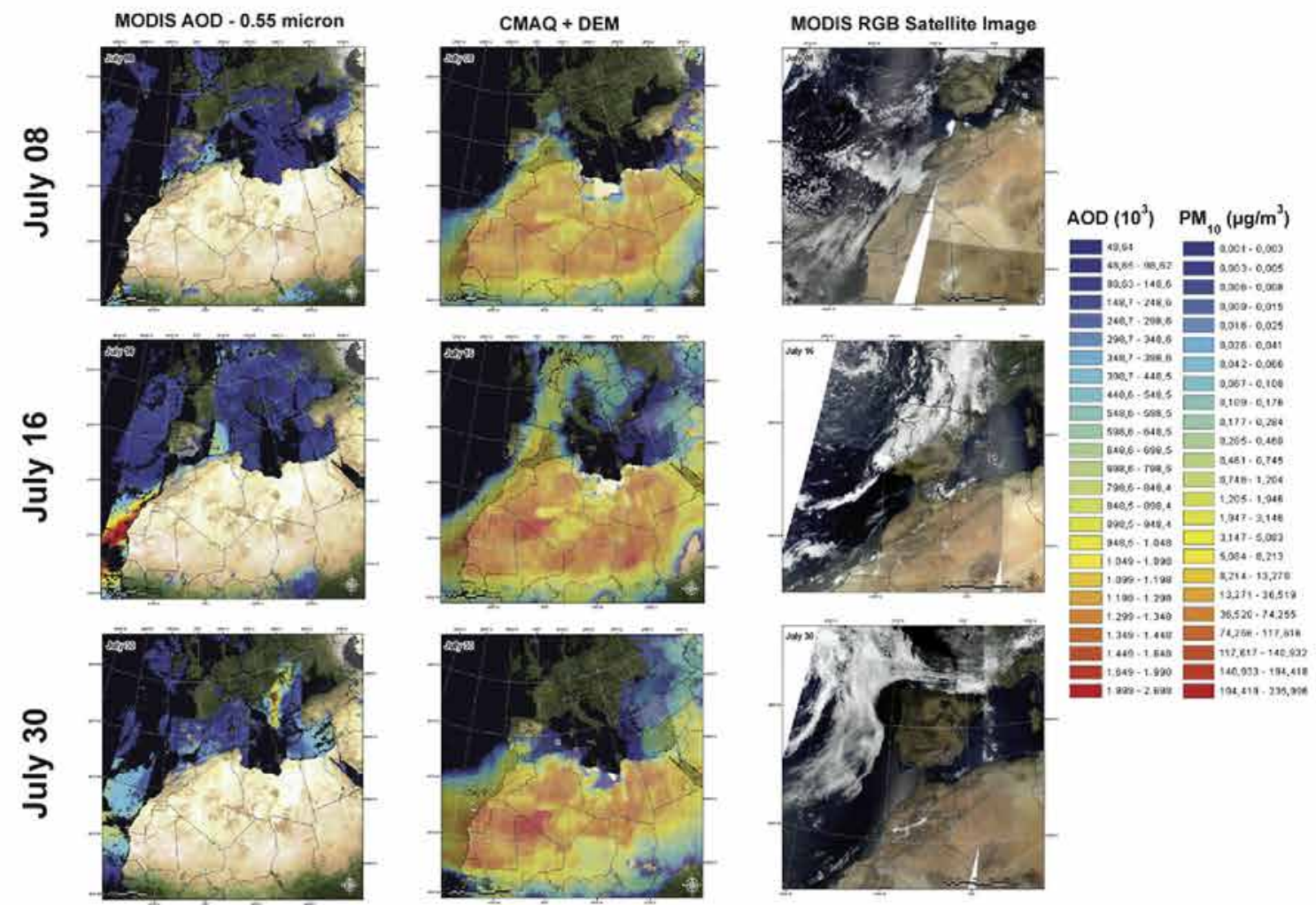

Fig. 4. Spatial representation of the MODIS AOD, the CMAQ + DEM PM 10 concentration and RGB satellite images for the three selected episodes. 


\section{Results and discussion}

\subsection{Study of the spatial performance of DEM}

A reasonable reproduction of the geographical patterns of the dust transport process is essential in order to consider the emission model as representative. Fig. 4 shows the spatial representation of the maximum $\mathrm{PM}_{10}$ concentration at ground level for the three selected episodes and is contrasted with the AOD data obtained from MODIS for the respective periods. Dust transport patterns are evident across the Mediterranean Sea for July 8 and 16, while the Atlantic intrusion is present to a different extent in the three episodes. The results can be further refined through MODIS RGB satellite images, that effectively represent a dust cloud moving across the Mediterranean and westbound the coast of Africa. Specifically for July 16 , where the highest dust concentrations were registered, the dust introduction into Central Europe attested by the MODIS data is also reproduced by CMAQ + DEM. Additionally, DEM is able to predict the influence of dust emissions other than the Sahara desert, such as the Iraqi and Arabian deserts. Dust transport from these areas to the Eastern Mediterranean region is evident for July 16 and 30 (Fig. 4).

Fig. 5 shows the vertical distribution of the $\mathrm{PM}_{10}$ concentration according to CMAQ + DEM over the CALIPSO satellite routes, simultaneously compared to the results yielded by the space-based measurements (backscatter profiles). In general, it can be seen that the simulation results from DEM for the three selected dates capture the plume structure well enough, although maximum predicted PM concentration is closer to the surface level than they actually are according to satellite observations. In the three selected episodes, dust aerosol clouds are represented in the CALIPSO profiles with a bright yellow hue, while clouds are depicted in cyan (Badarinath et al., 2010). On July 08 DEM predicts dense $\mathrm{PM}_{10}$ concentration columns over Senegal, and Mauritania, which can rise up to $6 \mathrm{~km}$ above ground level. Although the plume predicted by DEM is narrower than the one detected by CALIPSO, it does reproduce part of the noticeable dust outpost over the western coast of North Africa.

The trajectory of CALIPSO on July 16th describes the typical pathway of a Saharan dust outbreak being transported into the Mediterranean basin, covering from southern Mali to southwestern Sweden. The plume structure has been captured by DEM, showing dust clouds rising over $7 \mathrm{~km}$ above ground, although not as intensely as evidenced by CALIPSO. The dust transport process is evident over the coordinates that correspond to the Mediterranean gap $\left(\sim 36-42^{\circ} \mathrm{N}, 3-6^{\circ} \mathrm{E}\right)$ and reaches latitudes as high as $55^{\circ}$. Over the coordinates of the Balearic Islands $\left(\sim 40^{\circ} \mathrm{N}, 5^{\circ} \mathrm{E}\right)$, DEM clearly reproduces the intrusion observed by CALIPSO (Fig. 5).

The daytime pass of CALIPSO of July 30 was chosen to assess the vertical distribution of dust over the Atlantic Ocean avoiding dust clouds directly over the Sahara desert. For this date, DEM does catch the dust cloud being immediately transported from the desert into the Canary Islands in both, width and height. However, DEM fails to depict the thin dust layer that is being generated immediately above the ocean's surface and transported northwards according to the observations of CALIPSO.
July 08

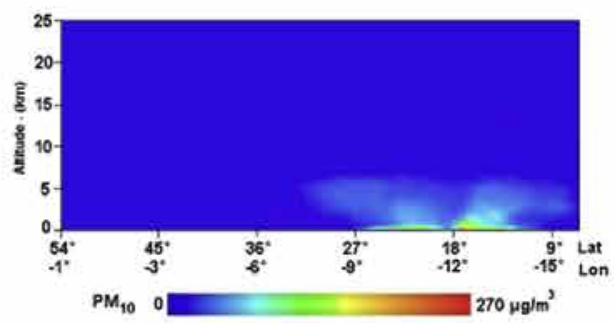

July 16

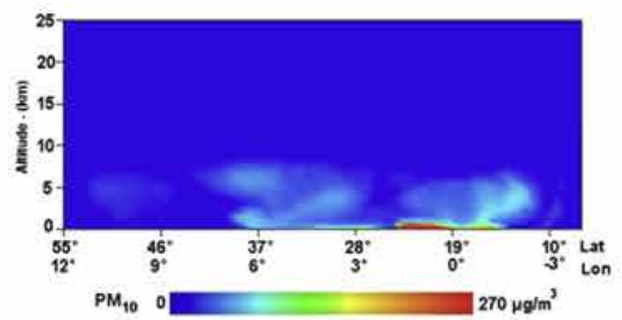

July 30

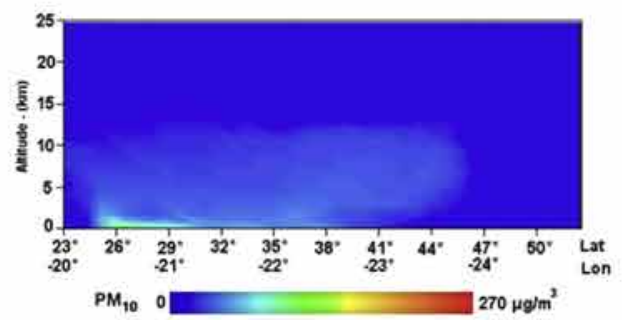

CALIPSO
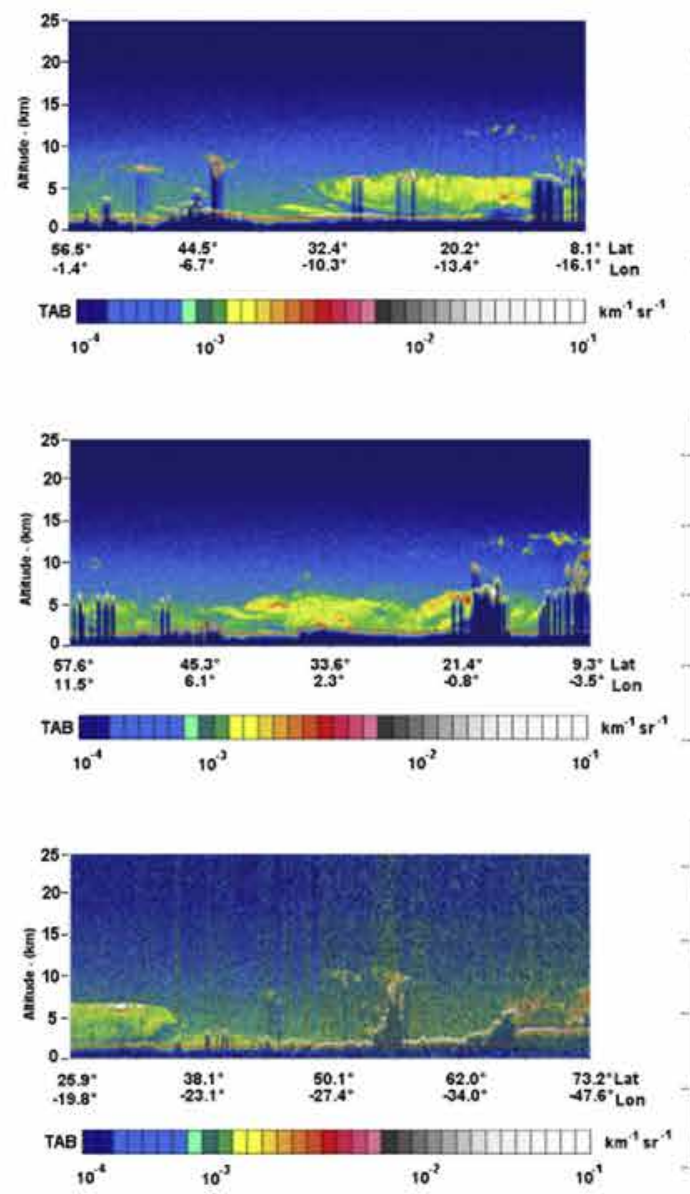

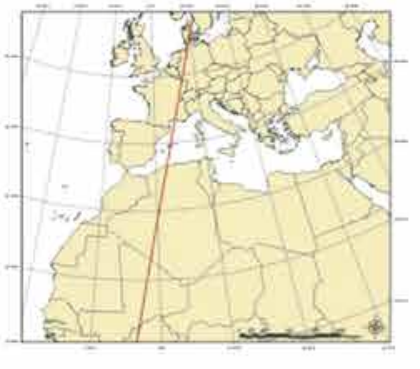

SATELLITE ROUTE
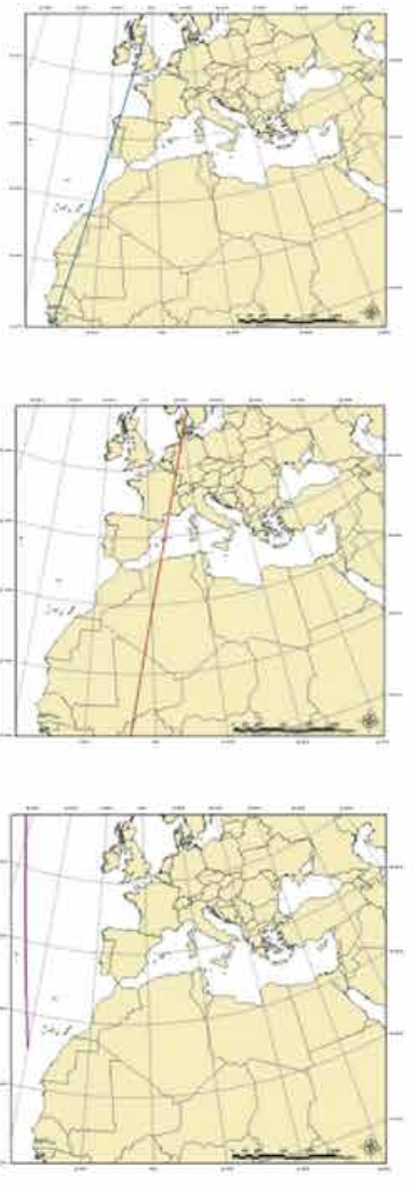

Fig. 5. Vertical distribution of the $\mathrm{PM}_{10}$ concentration/TAB along the selected satellite route lines. 


\subsection{Study of the temporal performance of DEM}

The evaluation of the ability of CMAQ + DEM to capture temporal patterns of dust transport was carried out through the correlation coefficient $(R)$ between observed AOT (AERONET) and ground-level $\mathrm{PM}_{10}$ predicted by the model. Since the $\mathrm{PM}_{10}$ and AOT values are provided with 1 -h resolution, high correlation coefficients are indicative of a good description of the temporal evolution (USEPA, 2007). Data from 44 locations relatively close to the two main zones of Saharan dust transport (the Atlantic coast and the western Mediterranean basin) were selected (Fig. 1).

Table 1 shows the values of the correlation coefficients $(R)$ computed for the CMAQ simulation vs. CMAQ + DEM, as well as the absolute difference between both figures. The incorporation of DEM to the AQM resulted in a general improvement of ground level PM levels. 6 out of the 44 stations were unaffected $(\Delta R=0)$ since there was no Saharan dust transport observed nor predicted in these locations (far from dust transport pathways) during the episode modelled. In 5 locations CMAQ + DEM yielded worse results $(\Delta R<0)$. This performance decrease is caused by slight deviations of modelled meteorological fields that bring about errors in the temporal or spatial distribution of dust. The improvement in the correlation level was in some cases noticeable: for ERDM $\Delta R=0.784$ and for ISPR, $\Delta R=0.754$. The mean $\Delta R$ for the 44 AERONET station reached 0.146 , which although modest, reveals an overall improvement in the prediction of $\mathrm{PM}_{10}$.

It is worth noting that the correlation coefficients calculated for the CMAQ simulation at the stations located within the Sahara desert (AGOU, BANZ, CINZ, DAKR, MSOA, TMNR) equalled zero because no anthropogenic $\mathrm{PM}_{10}$ emissions were considered for these areas, since the SERCA scope and modelling domains focus on Europe. This fact resulted in a very low $\mathrm{PM}_{10}$ concentration at these sites that did not match the temporal evolution of the AOT measurements. However, CMAQ + DEM notably increased the $R$ values, pointing out the influence of the dust-related processes at these locations.

Fig. 6 illustrates the results for 4 representative locations throughout the Canary Islands (IZNA). Southern Spain (AREN) and Northern Africa (RASE and BLID). AOT values provided by MODIS are included for additional reference.
BLID (Fig. 6a) and RASE (Fig. 6b) are examples of locations strongly affected by dust transport were the DEM module successfully captures the Saharan influence, improving thus the $\mathrm{PM}_{10}$ predictions of CMAQ alone. It can be observed how CMAQ + DEM neatly reproduced the AOT peak observed on 8th and 16th July in BLID and the strong dust intrusion at RASE observed in the 8th July.

In the case of AREN (Fig. 6c), CMAQ + DEM was able to reproduce the mid-July dust peak with a certain delay, while CMAQ missed it completely. For the rest of the month, CMAQ + DEM preserved the tendency, which was not the case for CMAQ. This station may be representative of locations far from the African dust sources, were the DEM module improves the behaviour of the model but not as much as in closer monitoring stations such as BLID or RASE.

Finally, IZNA in the Canary Islands (Fig. 6d) revealed that CMAQ + DEM and CMAQ alone performed very similarly, since most of $\mathrm{PM}_{10}$ corresponds to sea salt, accurately captured by the standard model. Although very close to the African continent, the Saharan dust reaching the Canary Islands in this particular period was small (only significant for 30th July) and therefore it is deem correct that the CMAQ + DEM results look very similar to those of CMAQ alone.

\subsection{Study of the performance in $P M_{10}$ predictions}

The analysis in previous sections focused only on the analysis of the system behaviour in terms of its spatial and temporal congruence. Yet, an analysis regarding the model performance in terms of its qualitative ability to improve the $\mathrm{PM}_{10}$ predictions is useful to determine the performance of the dust module. Fig. $7 \mathrm{a}$ represents a scatter plot of the mean monthly $\mathrm{PM}_{10}$ concentration value for both predictions (CMAQ and CMAQ + DEM) and the observations at the corresponding monitoring locations (the 20 monitoring stations from AirBase listed in Table A.2).

In general, a good agreement between measurements and observations at Atlantic locations (blue script) can be seen, with four stations (AVEI, VERM, VILL, CAND) near the $y=x$ line. On the other hand, most western Mediterranean locations (orange script) show poor correlations basically due to the sensitive bias they exhibit towards underestimation if compared to observations, being MALL

Table 1

AOT $-\mathrm{PM}_{10}$ correlation coefficients computed for the AERONET stations.

\begin{tabular}{|c|c|c|c|c|c|c|c|}
\hline $\begin{array}{c}\text { Station } \\
\text { Code }\end{array}$ & $\mathbf{R}_{\text {CMAQ }}$ & $\mathbf{R}_{\text {CMAQ+DUSTER }}$ & $\mathbf{A R}$ & $\begin{array}{c}\text { Station } \\
\text { Code }\end{array}$ & $\mathbf{R}_{\text {CMAQ }}$ & $\mathbf{R}_{\text {CMAQ+DUSTER }}$ & $\Delta \mathbf{R}$ \\
\hline AGOU & 0.000 & 0.551 & 个 0.551 & KARL & 0.369 & 0.306 & $\psi_{-0.063}$ \\
\hline AREN & 0.398 & 0.466 & ค 0.068 & LAEG & 0.389 & 0.328 & $\downarrow_{-0.061}$ \\
\hline AVGN & 0.467 & 0.702 & $\uparrow 0.235$ & LAGU & 0.437 & 0.674 & ค 0.237 \\
\hline BANZ & 0.000 & 0.042 & $\uparrow 0.042$ & LANN & 0.880 & 0.880 & 0.000 \\
\hline BARC & 0.079 & 0.305 & 0.226 & LECC & 0.513 & 0.564 & ^ 0.051 \\
\hline BLID & 0.385 & 0.66 & 0.275 & LEFG & 0.964 & 0.964 & 0.000 \\
\hline BUCR & 0.561 & 0.788 & 0.227 & LEIP & 0.493 & 0.547 & 0.054 \\
\hline BURJ & 0.172 & 0.194 & 个 0.022 & LILL & 0.395 & 0.412 & 个 0.017 \\
\hline CACE & 0.268 & 0.246 & -0.022 & MODE & 0.189 & 0.281 & 0.092 \\
\hline CARP & 0.403 & 0.632 & ๙ 0.289 & MOLD & 0.331 & 0.351 & 0.020 \\
\hline CBDR & 0.910 & 0.910 & 0.000 & MSOA & 0.000 & 0.074 & ค 0.074 \\
\hline CHBL & 0.110 & 0.110 & 0.000 & OBER & 0.496 & 0.614 & 个 0.118 \\
\hline CINZ & 0.000 & 0.451 & ค 0.451 & OBSR & 0.403 & 0.632 & 个 0.229 \\
\hline CRET & 0.254 & 0.551 & 个 0.297 & PALE & 0.071 & 0.259 & 个 0.188 \\
\hline DAKR & 0.000 & 0.261 & ค 0.261 & PALS & 0.464 & 0.519 & 个 0.055 \\
\hline ERDM & 0.042 & 0.826 & 0.784 & RASE & 0.542 & 0.766 & 个 0.224 \\
\hline EVOR & 0.225 & 0.421 & 个 0.196 & ROME & 0.534 & 0.602 & 0.068 \\
\hline FONT & 0.950 & 0.950 & 0.000 & SAAD & 0.544 & 0.778 & 个 0.234 \\
\hline GRND & 0.578 & 0.498 & -0.080 & SDBK & 0.308 & 0.348 & 0.040 \\
\hline ISDG & 0.801 & 0.778 & $\psi_{-0.023}$ & SEBL & 0.203 & 0.203 & 0.000 \\
\hline ISPR & 0.179 & 0.933 & 个 0.754 & TMNR & 0.000 & 0.205 & 0.205 \\
\hline IZNA & 0.538 & 0.551 & 个 0.013 & VENI & 0.202 & 0.256 & 个 0.054 \\
\hline
\end{tabular}



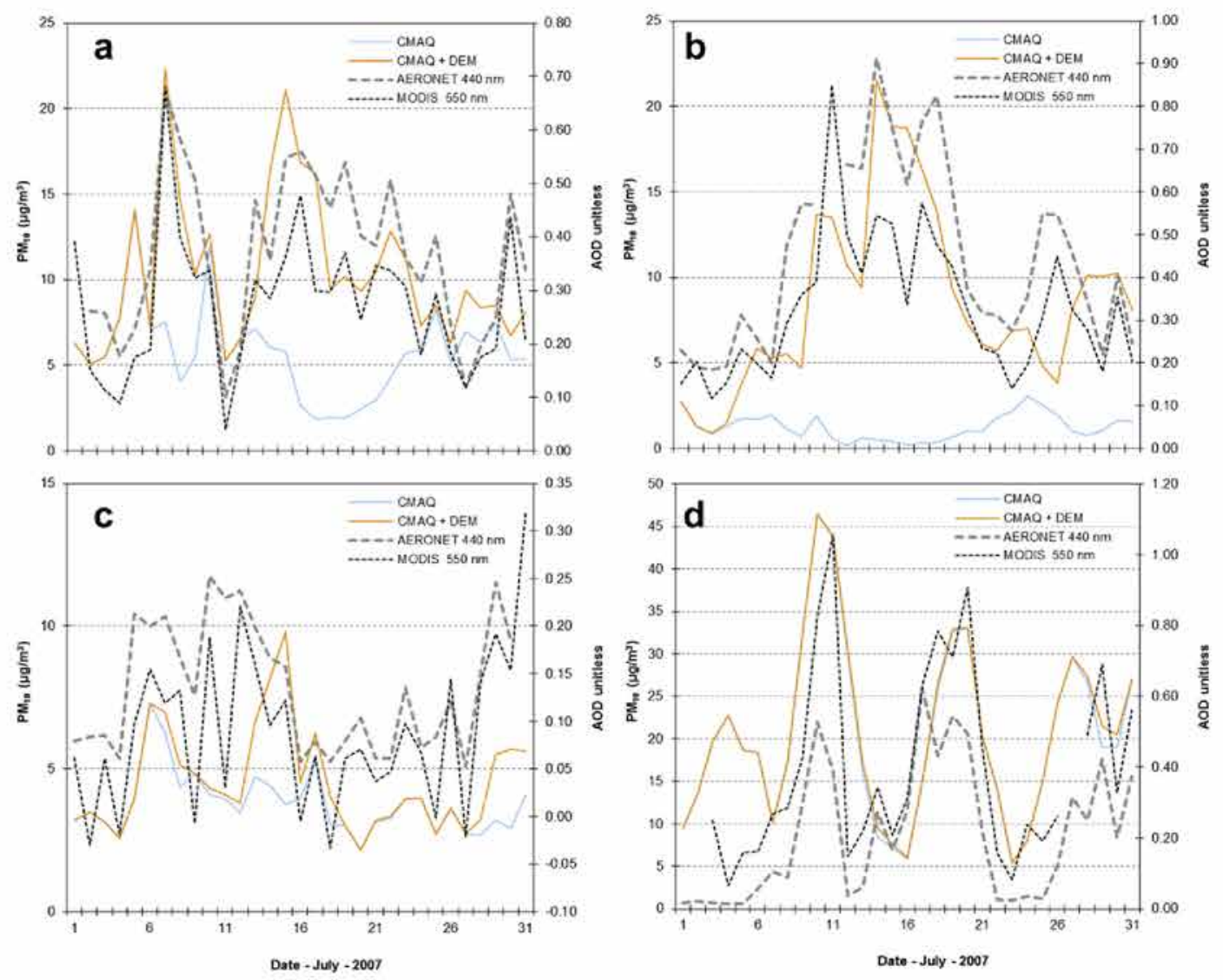

Fig. 6. Temporal AOT/PM 10 comparison at Blida (a), Ras El Ain (b), El Arenosillo (c) and Izaña (d).

the most evident example. Additionally, some eastern Mediterranean locations (pink script) show moderate correlation degrees (ZAGR, FINO) while some others show poor statistical correspondence (REKT, AGMR). Nevertheless, the incorporation of DEM into the modelling system increases hourly $\mathrm{PM}_{10}$ concentration in the south-eastern part of the Iberian Peninsula up to $25 \mu \mathrm{g} \mathrm{m}^{-3}$. As for daily average $\mathrm{PM}_{10}$ concentration values (a relevant parameter from the air quality compliance point of view) increments up to $14 \mu \mathrm{g} \mathrm{m}^{-3}\left(9 \mu \mathrm{g} \mathrm{m}^{-3}\right.$ in the centre of Spain) are found ( 28 and $18 \%$ of the $\mathrm{PM}_{10}$ limit value respectively). The increase in $\mathrm{PM}_{10}$ predictions reveals that the application of DEM results in accounting an additional source of particles that was being overlooked by the traditional modelling approach. Still, it emphasises the lack of accounting of other particle emission sources because the gap between observations and predictions is still sizeable.

The evaluation of the hourly resolved $\mathrm{PM}_{10}$ concentration dataset is addressed in Fig. $7 \mathrm{~b}$, which has been drawn according to Taylor (2001). The correlation coefficients $(R)$ computed for each of
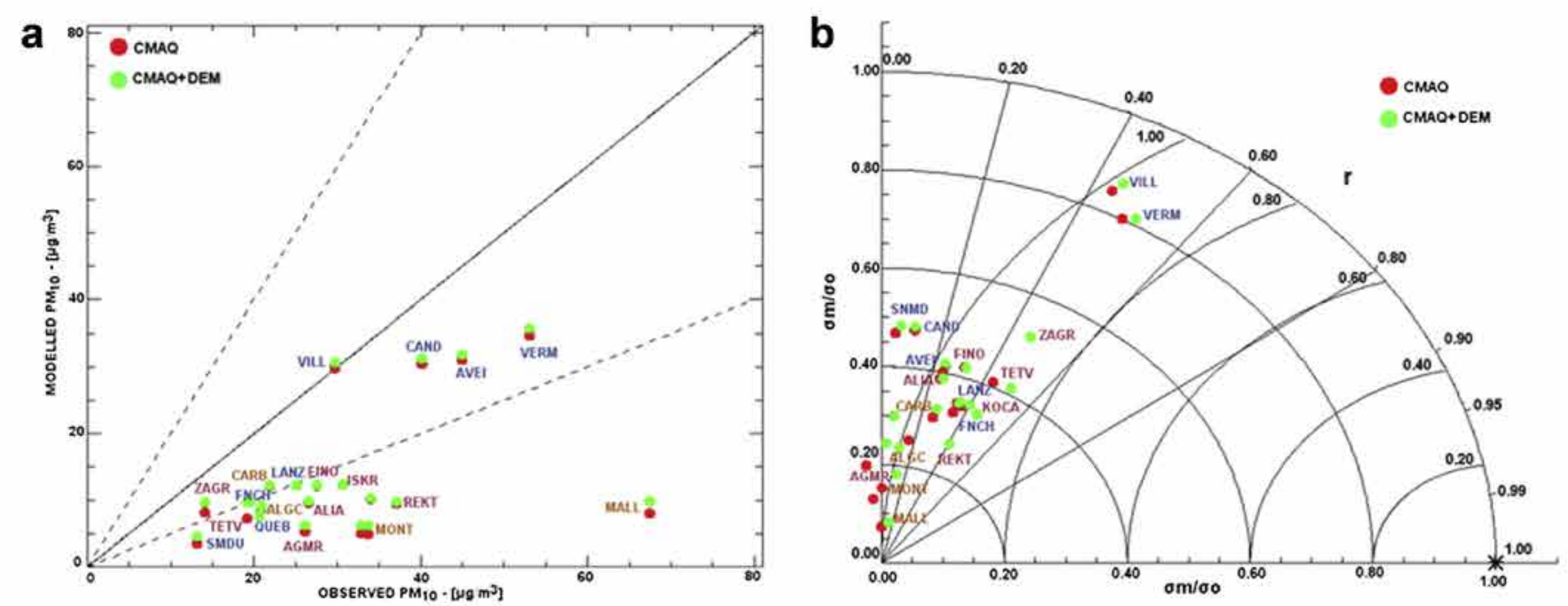

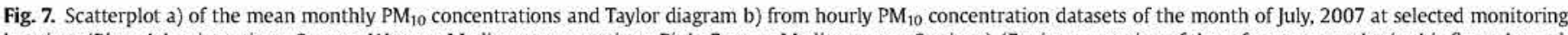

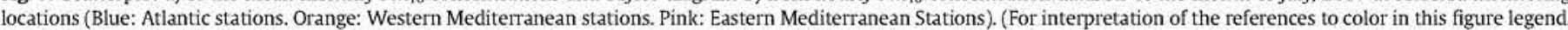
the reader is referred to the web version of this article.) 
Table 2

Model-to-observation indicators computed from hourly $\mathrm{PM}_{10}$ values.

\begin{tabular}{llllll}
\hline \multirow{2}{*}{$\begin{array}{l}\text { Statistic } \\
\text { indicator }\end{array}$} & \multicolumn{2}{l}{ CMAQ + DEM } & & \multicolumn{2}{l}{ CMAQ } \\
\cline { 2 - 3 } \cline { 5 - 6 } & Mean & Max-Min & & Mean & Max-Min \\
\hline MFB (\%) & -70 & 2 to -147 & & -83 & 4 to -148 \\
MFE (\%) & 83 & $146-27$ & & 84 & $151-30$ \\
$R$ & 0.48 & $0.73-0.14$ & & 0.33 & $0.76-0.02$ \\
\hline
\end{tabular}
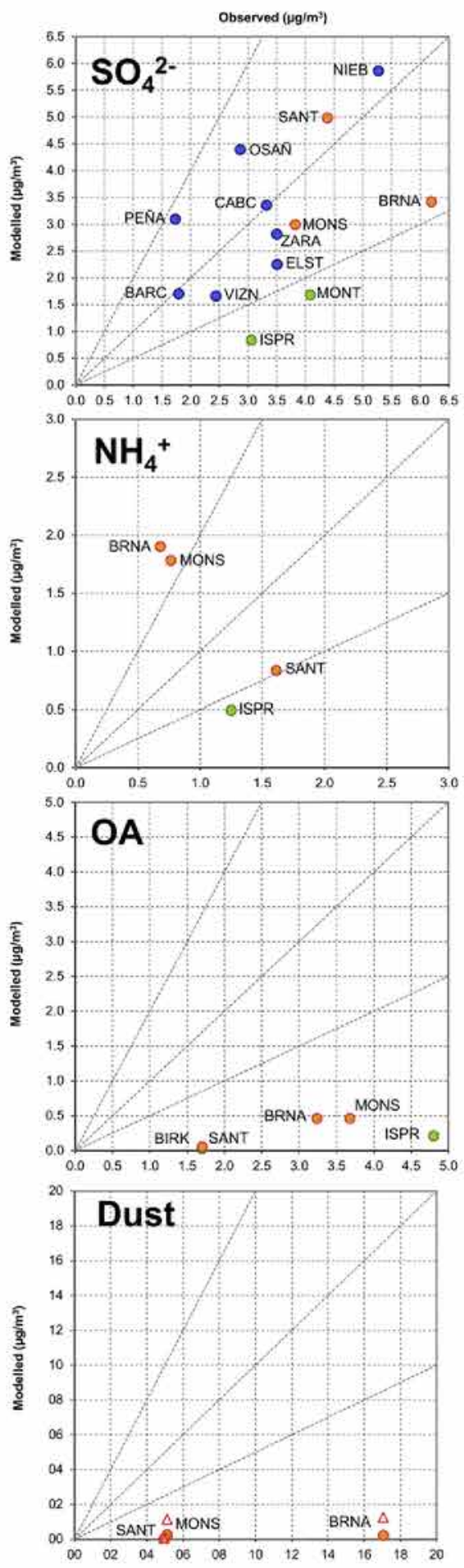

Observed $\left(\mu g / \mathrm{m}^{3}\right)$ the stations are, in every case below $R=0.55$. Most of the dots are located within the lower-left region of the diagram, which usually suggests the presence of systematic errors (Thunis et al., 2011). These errors are usually frequent when models are fed with emissions that have been underestimated or have not been accounted completely, producing error-prone predictions. It can be seen that the application of the DEM modules implies improvements in amplitude (observed and predicted standard deviation
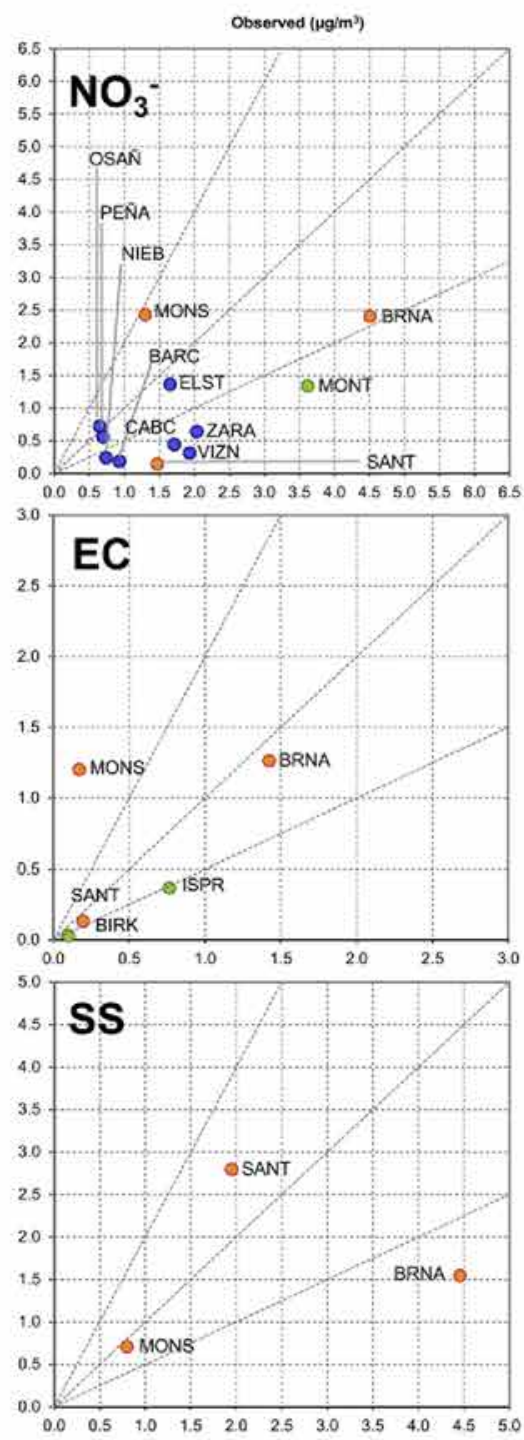

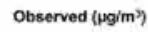

\section{Monitoring stations \\ EMEP (Spain) \\ - EMEP (others) \\ - IDAEA-CSIC}

$\mathrm{PM}_{10}$ components

$$
\begin{array}{lc}
\mathrm{SO}_{4}{ }^{2-} \text { - Suphate } & \mathrm{NO}_{3}{ }^{-} \text {- Nitrate } \\
\mathrm{NH}_{4}{ }^{+} \text {- Ammonium } & \mathrm{EC} \text { - Elemental } \\
\mathrm{OA} \text { - Organic aerosol } & \text { carbon }
\end{array}
$$$$
\text { Dust - Mineral aerosol SS - Sea salt }
$$

Model run

$$
O C M A Q \quad \triangle C M A Q+D E M
$$

Fig. 8. Modelled vs. Observed values for the main $\mathrm{PM}_{10}$ components. 
Table 3

Model-to-observation indicators computed from daily speciated $\mathrm{PM}_{10}$ values.

\begin{tabular}{lllrrrr}
\hline $\mathrm{PM}_{10}$ component & $\begin{array}{l}\text { Observed } \\
\text { mean } \\
\left(\mu \mathrm{g} \mathrm{m}^{-3}\right)\end{array}$ & $\begin{array}{l}\text { Modelled } \\
\text { mean } \\
\left(\mu \mathrm{g} \mathrm{m}^{-3}\right)\end{array}$ & $N$ & MFB $(\%)$ & MFE $(\%)$ & $R$ \\
\hline Sulphates & 3.3 & 2.8 & 320 & -19.4 & 53.3 & 0.61 \\
Nitrates & 1.6 & 0.8 & 292 & -87.9 & 107.5 & 0.20 \\
Ammonium & 1.1 & 1.0 & 56 & -20.7 & 89.1 & 0.63 \\
Elemental carbon & 0.6 & 0.6 & 65 & -23.7 & 80.9 & 0.48 \\
Organic aerosol & 3.6 & 0.2 & 65 & -173.1 & 173.1 & 0.44 \\
Sea salt & 2.4 & 1.6 & 28 & -29.3 & 61.9 & 0.47 \\
Mineral dust & 9.3 & 0.2 & 28 & -189.0 & 189.0 & 0.24 \\
Mineral dust & 9.3 & 0.9 & 28 & -169.0 & 169.0 & 0.39 \\
$\quad$ (CMAQ + DEM) & & & & & & \\
\hline
\end{tabular}

$N$ - number of observations ( $24 \mathrm{~h}$ average values).

ratio) but mainly in phase $(R)$, which is consistent with the results shown in Section 4.2.

Table 2 summarizes the basic statistical analysis for the complete set of $\mathrm{PM}_{10}$ monitoring stations for both simulation modes. Mean fractional bias (MFB), Mean fractional error (MFE) and correlation coefficient $(R)$ are selected as a minimum set of parameters useful to provide information on relative and absolute errors as well as temporal agreement between observed and modelled values. An analysis taking into account the performance criteria for MFB and MFE ( $\pm 50 \%$ and $75 \%$ respectively) as specified by Boylan and Russell (2006) reveals that the CMAQ + DEM simulation mode yielded values closer to those criteria than those of CMAQ alone. Moreover, the CMAQ + DEM yielded an average $R$ coefficient value of 0.48 , which is higher than the specified $P_{10}$

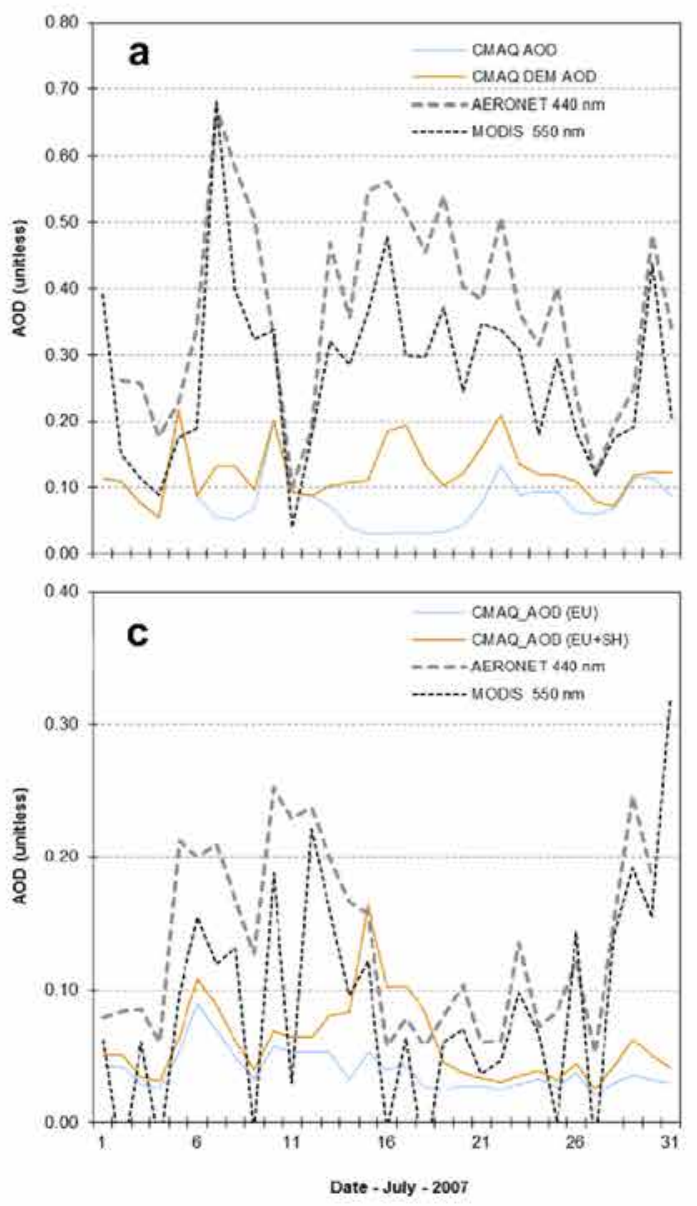

goal value (0.45) suggested by Thunis et al. (2011), unlike CMAQ alone (0.33).

It seems clear that the inclusion of Saharan dust improves modelled results. However, it is interesting to look into PM components in order to understand whether the systematic underprediction of $\mathrm{PM}_{10}$ is due only to dust or there are other sources or processes misrepresented in the model. 24-h average speciated PM measurements for the period modelled were available in 14 monitoring stations (Fig. 1, Table A.3). The main results are summarized in Fig. 8 and Table 3.

The model exhibits a reasonable performance for sulphate aerosols with all predicted values within a factor of 2 to observed values except for ISPR and MONT. According to the results, CMAQ presents a global underestimation of $0.5 \mu \mathrm{g} \mathrm{m}^{-3}$ of sulphates in $\mathrm{PM}_{10}$, with a correlation of 0.61 . The satisfactory results for this component points out to a correct representation of anthropogenic sources responsible for $\mathrm{SO}_{2}$ emissions and gas-to-particle conversion processes (Park et al., 2006). Ammonium is also well depicted by the model, with an MFB of approximately $20 \%$. Although nitrates are mainly also formed from anthropogenic precursors, their concentration depends on complex phenomena involving several chemical species and meteorological variables (Zhang et al., 2000). Despite being precise enough for a series of locations (such as OSAÑ, PEÑA or ELST), CMAQ results are poorer (MFE above $100 \%$ and $R$ global coefficient of 0.2 ). Nonetheless, this would only contribute $0.8 \mu \mathrm{g} \mathrm{m}^{-3}$ as an average to total $\mathrm{PM}_{10}$ underestmation. From the limited data available it can be drawn that elemental carbon is accurately represented (MFE below 25\%) and a global compensation of errors. From the results of the BRNA station it can be inferred that the model is
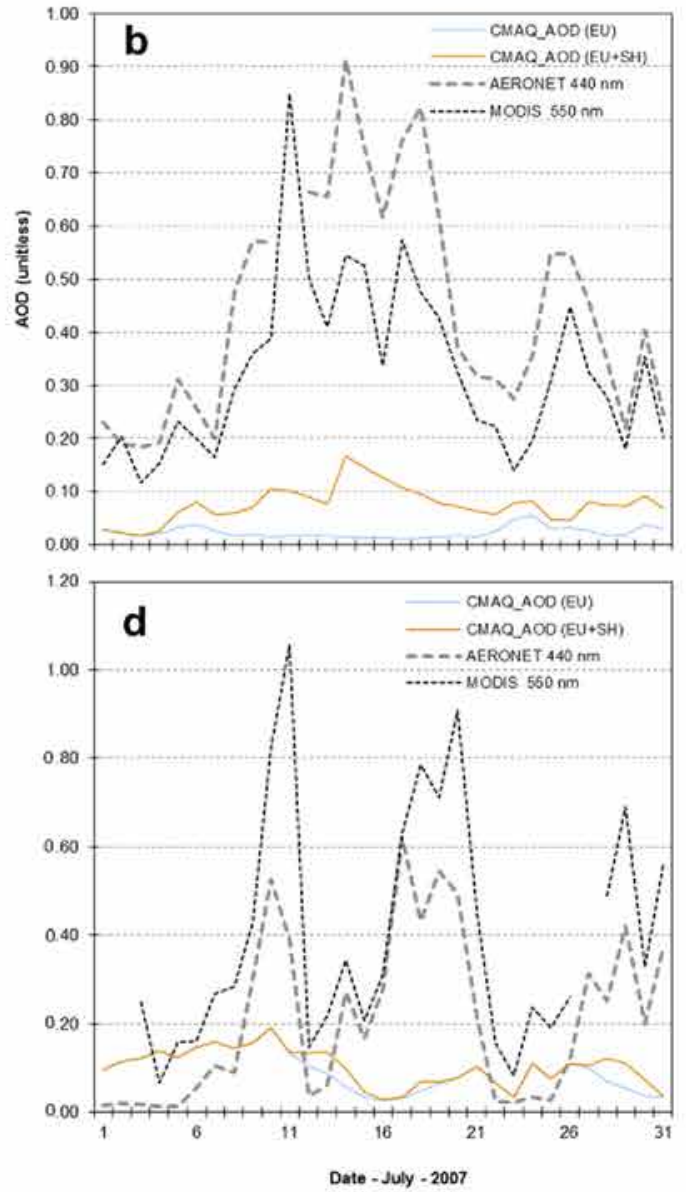

Date - July - 2007

Fig. 9. Observed (AERONET and MODIS) vs. CMAQ-derived AOT at Blida (a), Ras El Ain (b), El Arenosillo (c) and Izaña (d). 
capturing reasonably well the influences from urban combustion sources. As for organic aerosols, they are mainly missed by the model. Previous studies identified important underestimations of this PM fraction e.g. Pay et al. (2012) in the Iberian Peninsula or Appel et al. (2008) in the United States. These and other authors (Morris et al., 2006) attribute the underestimation, among other causes, to the lack of relevant secondary organic aerosol (SOA) formation paths such as the oxidation of isoprene or sesquiterpenes, not included in CMAQ v4.6 (AERO4 aerosol module). Although the correlation coefficient is acceptable (0.44), the model exhibits a large and systematic underestimation (MFB $=$ MFE) that accounts for an absolute bias of $-3.4 \mu \mathrm{g} \mathrm{m}^{-3}$ of total $\mathrm{PM}_{10}$ mass. Sea salt is sensibly well represented (MFB below 30\%), and it is only important on coastal areas (BRNA or SANT). The analysis clearly presents windblown dust as the main deficiency in the representation of $\mathrm{PM}_{10}$. According to the data available (limited to IDAEA-CSIC monitoring campaigns), mineral matter is the single most important component of the PM coarse fraction, even under non-episode conditions. Most sources of natural dust are missing in the emission inventory used and therefore, dust is underestimated by $9.1 \mu \mathrm{g} \mathrm{m}^{-3}$ as an average (MFB $=-189 \%$ ). The implementation of the DEM module improves modelled results, reducing MFB and MFE by $20 \%$ and significantly increasing $R$ (from 0.24 to 0.39 ). The total underestimation remains large since only Saharan dust is taken into account, being the remaining dust local sources still missed.

\subsection{Study of the performance in AOT predictions}

This section summarises a complementary analysis of the modelled $\mathrm{PM}_{10}$ vs. AOT observations shown in Section 4.2. CMAQderived AOT is compared to MODIS and AERONET AOT values to provide a more precise image of the capabilities of CMAQ + DEM. Fig. 9 shows the results for the four locations analysed in Fig. 6.

It can be seen that the general temporal trend of modelled AOT correspond to that of ground level $\mathrm{PM}_{10}$ and that the CMAQ + DEM derived AOT loosely follows the pattern depicted by MODIS and AERONET observations. However, the improvement of $R$ coefficients is much lower than those presented in Section 4.2. The application of the DEM module yielded an $\Delta R$ of 0.275 and 0.224 for BLID and RASE stations for the AOT-PM10 series. When AOT-AOT $R$ coefficients are computed, those $\Delta R$ of turn into 0.049 and 0.284 respectively. For distant locations AOT $\Delta R$ are even negative, although very small in magnitude, due to a temporal mismatch of AOT predicted and observed peaks. AOT predictions however, show a consistent improvement in absolute values. CMAQ + DEM still underpredicts AOT values, but MFB (\%) are decreased by $26.4,34.6,30.8$ and $8.6 \%$ respectively for BLID (Fig. 9a), RASE (Fig. 9b), AREN (Fig. 9c) and IZNA (Fig. 9d). Underestimations of CMAQ-derived AOT values have been reported by several authors before (Roy et al., 2007; Park et al., 2011).

This may indicate that suspended dust is rapidly deposited or insufficiently transported aloft, as suggested also by the results shown in Section 4.1. Therefore, the influence of dust transport is more evident at surface level. This tendency is more evident as the distance to the source increases. Ground-surface $\mathrm{PM}_{10}$ levels are taken from the average concentration predicted by CMAQ in the first vertical layer, which is very thin (around $7 \mathrm{~m}$ ) and has very little influence in the vertical integration involved in AOT computation (Binkowski and Roselle, 2003). This would explain why the improvements are, in general, more evident for $\mathrm{PM}_{10}$ (Fig. 6) than for AOT (Fig. 9).

\section{Conclusions}

The primary objective of implementing and evaluating a dust emission module is the need of filling the deep information gap that exists when describing the emission processes related with natural dust emissions and air quality. This paper presents the implementation and application of a dust module (DEM) into the WRF-SMOKE-CMAQ mesoscale modelling system (AQM). The emission scheme is based on that of Gillette and Passi (1988) and later modified by Ginoux et al. (2004). In general, the evaluation of the overall predictions of the modelling system against independent ground-based $\mathrm{PM}_{10}$ observations and satellite products showed an acceptable performance in the reproduction of the actual dust emission and transport patterns in the period analysed (July 2007). DEM has been found useful to increase CMAQ skills for the assessment of ground-level $\mathrm{PM}_{10}$ since it was able to capture dust intrusion episodes, reproducing the Atlantic and western Mediterranean dust transport routes. It succeeded identifying Saharan dust as an important natural source affecting air quality in southern European countries, especially Spain with contributions to daily $\mathrm{PM}_{10}$ average concentrations up to $14 \mu \mathrm{g} \mathrm{m}^{-3}$.

Further spatiotemporal coherence was observed after a correlation analysis of the AOT and surface level $\mathrm{PM}_{10}$ at 44 stations all over Europe, Africa and Asia (AERONET and EMEP monitoring networks). The temporal agreement between observed and predicted $\mathrm{PM}_{10}$ levels was clearly improved, increasing the global correlation coefficient from 0.33 (CMAQ) to 0.48 (CMAQ + DEM). Relative bias was reduced by $13 \%$ overall. A detailed analysis of $\mathrm{PM}_{10}$ composition (limited to the information available) clearly shows that the main reasons for the systematic underprediction of $\mathrm{PM}_{10}$ in Spain is mostly due to the limitations of the system to reproduce windblown dust, the most important component of the PM coarse fraction in the monitoring sites with specific measurements of the mineral fraction in the period analysed. Therefore total $\mathrm{PM}_{10}$ underestimation remains large since only Saharan dust is taken into account, being the remaining dust local sources still missed in the emission inventories used in this study. Organic aerosols are also poorly simulated, while sulphate, ammonium, sea salt and elemental carbon are modelled reasonably well.

Both the qualitative (comparison of vertical profiles with CALIPSO) and quantitative (comparison of modelled and observed AOT) analysis suggest that PM concentration is underestimated in the middle troposphere. This may indicate that suspended dust is rapidly deposited or insufficiently transported aloft according to the model formulation. This shortcoming of the model along with SOA representation and the inclusion of local dust sources may constitute interesting future research lines to improve CMAQ capabilities to simulate particulate matter. In particular it would be interesting to explore whether the misrepresentation of natural dust may be related to emission issues (processes explicitly considered and number of size bins) or the treatment of PM dynamics (advection, vertical transport and deposition) within CMAQ.

\section{Acknowledgements}

This study is developed under research contract 058/PC08/318.1 of the Spanish Ministry of Environment (MARM) in the framework of the National Plan of Scientific Research, Development and Technological Innovation 2008-2011. The CMAQ modelling system was made available by the USEPA and it is supported by the Community Modelling and Analysis System (CMAS) Center. MODIS and CALIPSO products are provided by the NASA Earth Observing System. The authors also acknowledge the use of emission datasets and monitoring data from EMEP, the Spanish and Portuguese Ministries of the Environment. Comments and suggestions made by both reviewers have been very useful to improve the original manuscript and are thankfully acknowledged. 


\section{Appendix}

Table A.1

Selected monitoring locations from AERONET ( $24 \mathrm{~h}$ resolution)

\begin{tabular}{|c|c|c|c|c|c|}
\hline Country & Station name & Station code & $X$ (decimal degrees $)$ & $Y($ decimal degrees $)$ & Observations \\
\hline \multirow[t]{2}{*}{ Algeria } & Blida & BLID & 2.88 & 36.51 & 30 \\
\hline & Tamanrasset & TMNR & 5.53 & 22.79 & 21 \\
\hline \multirow[t]{10}{*}{ France } & Avignon & AVGN & 4.76 & 43.71 & 29 \\
\hline & Carpentras & CARP & 5.05 & 44.08 & 30 \\
\hline & Fointainebleau & FONT & 2.68 & 48.40 & 5 \\
\hline & Lannion & LANN & -3.46 & 48.73 & 7 \\
\hline & Le Fauga & LEFG & 1.28 & 43.38 & 6 \\
\hline & Lille & LILL & 3.14 & 50.61 & 21 \\
\hline & Obernai & OBER & 7.54 & 48.44 & 12 \\
\hline & Observatoire & OBSR & 5.71 & 43.93 & 30 \\
\hline & Palaiseau & PALS & 2.20 & 48.70 & 17 \\
\hline & Toulon & TOUL & 4.87 & 43.93 & 30 \\
\hline \multirow[t]{2}{*}{ Germany } & Karlsruhe & KARL & 8.42 & 49.09 & 15 \\
\hline & Leipzig & LEIP & 12.43 & 51.35 & 12 \\
\hline Greece & Crete & CRET & 25.28 & 35.33 & 31 \\
\hline Israel & Sede Boker & SDBK & 34.78 & 30.85 & 31 \\
\hline \multirow[t]{6}{*}{ Italy } & ISDG & ISDG & 12.33 & 45.43 & 4 \\
\hline & Ispra & ISPR & 8.62 & 45.80 & 3 \\
\hline & Lecce & LECC & 18.11 & 40.33 & 28 \\
\hline & Modena & MODE & 10.94 & 44.63 & 31 \\
\hline & Rome & ROME & 12.64 & 41.84 & 31 \\
\hline & Venise & VENI & 12.51 & 45.31 & 30 \\
\hline \multirow[t]{2}{*}{ Mali } & Agoufou & AGOU & -1.48 & 15.34 & 27 \\
\hline & Cinzana & CINZ & -5.93 & 13.27 & 28 \\
\hline Moldova & Moldova & MOLD & 28.82 & 47.00 & 31 \\
\hline \multirow[t]{2}{*}{ Morocco } & Ras el Ain & RASE & -7.59 & 31.67 & 30 \\
\hline & Saada & SAAD & -8.15 & 31.62 & 31 \\
\hline \multirow[t]{2}{*}{ Niger } & Banizoumbou & BANZ & 2.66 & 13.54 & 27 \\
\hline & Maine Soroa & MSOA & 12.02 & 13.21 & 29 \\
\hline \multirow[t]{2}{*}{ Portugal } & Cabo da Roca & CBDR & -9.50 & 38.78 & 5 \\
\hline & Evora & EVOR & -7.91 & 38.56 & 31 \\
\hline Romania & Bucarest & BUCR & 26.03 & 44.34 & 18 \\
\hline Senegal & Dakar & DAKR & -16.96 & 14.39 & 29 \\
\hline \multirow[t]{8}{*}{ Spain } & Barcelona & BARC & 2.11 & 41.38 & 28 \\
\hline & Burjassot & BURJ & -0.41 & 39.51 & 29 \\
\hline & Caceres & CACE & -6.34 & 39.48 & 28 \\
\hline & El Arenosillo & AREN & -6.73 & 37.10 & 30 \\
\hline & Granada & GRND & -3.60 & 37.16 & 31 \\
\hline & Izana & IZNA & -16.49 & 28.31 & 31 \\
\hline & Laguna & LAGU & -16.32 & 28.48 & 24 \\
\hline & Palencia & PALE & -4.51 & 41.98 & 31 \\
\hline Switzerland & Laegeren & LAEG & 8.35 & 47.48 & 31 \\
\hline Turkey & Erdemli & ERDM & 34.25 & 36.56 & 6 \\
\hline Ukraine & Sebastopol & SEBL & 33.51 & 44.62 & 12 \\
\hline United Kingdom & Chilbolton & CHBL & -1.43 & 51.14 & 31 \\
\hline
\end{tabular}

Table A.2

Selected monitoring locations from AirBase ( $1 \mathrm{~h}$ resolution)

\begin{tabular}{|c|c|c|c|c|c|c|}
\hline Country & Station name & Station code & Station type & $X$ (decimal degrees) & $Y($ decimal degrees $)$ & Observations \\
\hline Croatia & Zagreb & ZAGR & Traffic & 16.03 & 45.82 & 744 \\
\hline Cyprus & Agia Marina & AGMR & Urban background & 33.05 & 35.04 & 744 \\
\hline \multirow[t]{3}{*}{ F.Y.R.O.M. } & Kocani & $\mathrm{KOCA}$ & Industrial & 22.41 & 41.91 & 744 \\
\hline & Rektorat & REKT & Traffic & 21.44 & 42.00 & 744 \\
\hline & Tetovo & TETV & Urban background & 20.97 & 42.00 & 744 \\
\hline \multirow[t]{2}{*}{ Greece } & Aliartos & ALIA & Rural (EMEP) & 23.09 & 38.36 & 744 \\
\hline & Finokalia & FINO & Rural (EMEP) & 25.69 & 35.34 & 744 \\
\hline ltaly & Montelibretti & MONT & Rural (EMEP) & 12.92 & 42.01 & 744 \\
\hline \multirow[t]{4}{*}{ Portugal } & Aveiro & AVEI & Traffic & -8.58 & 40.67 & 744 \\
\hline & Funchal & $\mathrm{FNCH}$ & Urban background & -16.91 & 32.64 & 744 \\
\hline & Quebedo & QUEB & Urban background & -8.90 & 38.49 & 744 \\
\hline & Vermoin & VERM & Urban background & -8.42 & 41.13 & 744 \\
\hline Slovenia & Iskrba & ISKR & Rural (EMEP) & 14.86 & 45.56 & 744 \\
\hline \multirow[t]{7}{*}{ Spain } & Algeciras & ALGC & Industrial & -5.29 & 36.43 & 744 \\
\hline & Candelaria & CAND & Urban background & -16.35 & 28.39 & 744 \\
\hline & Carboneras & CARB & Urban background & -3.26 & 36.84 & 744 \\
\hline & Lanzarote & LANZ & Urban background & -13.54 & 28.97 & 744 \\
\hline & Mallorca & MALL & Urban background & 2.65 & 39.57 & 744 \\
\hline & Sn Miguel Dueñas & SMDU & Rural & -6.52 & 42.59 & 744 \\
\hline & Villaverde & VILL & Rural & -6.48 & 42.61 & 744 \\
\hline
\end{tabular}


Table A.3

Selected monitoring locations for speciated $\mathrm{PM}_{10}$ data ( $24 \mathrm{~h}$ resolution)

\begin{tabular}{|c|c|c|c|c|c|c|}
\hline Country & Station name & Station code & Network & $X$ (decimal degrees) & $Y$ (decimal degrees) & Observations \\
\hline \multirow[t]{11}{*}{ Spain } & Montseny & MONS & CSIC & 2.35 & 41.77 & 10 \\
\hline & Barcelona & BRNA & CSIC & 2.12 & 41.37 & 10 \\
\hline & Santander & SANT & CSIC & -3.79 & 43.46 & 8 \\
\hline & Viznar & VIZN & EMEP & -3.53 & 37.23 & 31 \\
\hline & Niembro & NIEB & EMEP & -4.85 & 43.44 & 30 \\
\hline & Cabo de Creus & $\mathrm{CABC}$ & EMEP & 3.31 & 42.32 & 30 \\
\hline & Barcarrota & BARC & EMEP & -6.92 & 38.47 & 30 \\
\hline & Zarra & ZARA & EMEP & -1.10 & 39.08 & 24 \\
\hline & Peñausende & PEÑA & EMEP & -5.89 & 41.23 & 29 \\
\hline & Els Torms & ELST & EMEP & 0.73 & 41.39 & 30 \\
\hline & O Sabiñao & OSAÑ & EMEP & -7.70 & 42.63 & 29 \\
\hline \multirow[t]{2}{*}{ Italy } & Montelibretti & MONT & EMEP & 12.62 & 42.09 & 31 \\
\hline & Ispra & ISPR & EMEP & 8.62 & 45.79 & 28 \\
\hline Norway & Birkenes & BIRK & EMEP & 8.25 & 58.38 & 9 \\
\hline
\end{tabular}

\section{References}

APA (Portuguese Environmental Agency), 2010. National Inventory of Atmospheric Emissions in Portugal for Year 2007. National Ministry for Agriculture, Sea, Environment, and Territory Ordinance.

Appel, K.W., Bhave, P.V., Gilliland, A.B., Sarwar, G., Roselle, S.J., 2008. Evaluation of the community multiscale air quality (CMAQ) model version 4.5: sensitivities impacting model performance; part II - particulate matter. Atmospheric Environment 42, 6057-6066.

Badarinath, K.V.S., Kharol, S.K., Kaskaoutis, D.G., Sharma, A.R., Ramaswamy, V. Kambezidis, H.D., 2010. Long-range transport of dust aerosols over the Arabian Sea and Indian region - a case study using satellite data and ground - based measurements. Global Planet Change 72, 164-181.

Binkowski, F.S., Roselle, S.J., 2003. Models-3 community multiscale air quality (CMAQ) model aerosol component 1. Model description. Journal of Geophysical Research 108, 4183-4200.

Boldo, E., Linares, C., Lumbreras, J., Borge, R., Narros, A., García-Pérez, J., FernándezNavarro, P., Pérez-Gómez, B., Aragonés, N., Ramis, R., Pollán, M., Moreno, T. Karanasiou, A., López-Abente, G., 2011. Health impact assessment of a reduction in ambient $\mathrm{PM}_{2.5}$ levels in Spain. Environment International 37, 342-348.

Borge, R., Alexandrov, V., del Vas, J.J., Lumbreras, J., Rodríguez, E., $2008 \mathrm{a}$. A comprehensive sensitivity analysis of the WRF model for air quality applications over the Iberia Peninsula. Atmospheric Environment 42, 8560-8574

Borge, R., Lumbreras, J., Rodríguez, M.E., 2008b. Development of a high-resolution emission inventory for Spain using the SMOKE modelling system: a case study for the years 2000 and 2010. Environmental Modelling \& Software 23. 1026-1044.

Borge, R., López, J., Lumbreras, J., Narros, A., Rodríguez, M.E., 2010. Influence of boundary conditions on CMAQ simulations over the Iberian Peninsula. Atmospheric Environment 44, 2681-2695.

Boylan, J.W., Russell, A.G., 2006. PM and light extinction model performance metrics, goals, and criteria for three-dimensional air quality models. Atmospheric Environment 40, 4946-4959.

Byun, D.W., Ching, J.K.S., 1999. Science Algorithms of the EPA Models-3 Community Multi-scale Air Quality (CMAQ) Modeling System. EPA/600/R-99/030. USEPA National Exposure Research Laboratory, Research Triangle Park, NC

Byun, D.W., Schere, K.I., 2006. Review of the governing equations, computational algorithms, and other components of the Models- 3 community Multiscale Air Quality (CMAQ) modeling system. Applied Mechanics Reviews 59, 51-77.

Chin, M., Rood, R.B., Lin, S.J., Müller, J.F., Thompson, A.M., 2000. Atmospheric sulfur cycle simulated in the global model GOCART; model description and global properties. Journal of Geophysical Research 105, 671-687.

de Andrés, J.M., Borge, R., de la Paz, D., Lumbreras, J., Rodríguez, M.E., 2012. Implementation of a module for risk of ozone impacts assessment to vegetation in the Integrated Assessment Modelling system for the Iberian Peninsula Evaluation for wheat and Holm oak. Environmental Pollution 165, 25-37.

D'Almeida, G.A., 1986. A model for Saharan dust transport. Journal of Climate and Applied Meteorology 25, 903-916

Escudero, M., Castillo, S., Querol, X., Avila, A., Alarcón, M., Viana, M.M., Alastuey, A. Cuevas, E., Rodríguez, S., 2005. Wet and dry African dust episodes over eastern Spain. Journal of Geophysical Research 110, D18S08. http://dx.doi.org/10.1029/ 2004JD004731

Escudero, M., Querol, X., Avila, A., Cuevas, E., 2007. Origins of the exceedances of the European daily PM limit value in regional background areas of Spain. Atmospheric Environment 41, 730-744.

Gillette, D.A., Passi, R., 1988. Modeling dust emission caused by wind erosion. Journal of Geophysical Research 93, 233-242.

Ginoux, P., Chin, M., Tegen, I., Prospero, J., Holben, B., Dubovik, O., Lin, S.J., 2001. Sources and global distributions of dust aerosols simulated with the GOCART model. Journal of Geophysical Research 106, 255-273.
Ginoux, P., Prospero, J.M., Torres, O., Chin, M., 2004. Long-term simulation of global dust distribution with the GOCART model: correlation with North Atlantic Oscillation. Environmental Modelling and Software 19, 113-128.

Hatzianastassiou, N., Gkikas, A., Mihalopoulos, N., Torres, O., Katsoulis, B.D., 2009. Natural versus anthropogenic aerosols in the eastern Mediterranean basin derived from multiyear TOMS and MODIS satellite data. Journal of Geophysical Research 114, D24202. http://dx.doi.org/10.1029/2009JD011982.

Holben, B.N., Eck, T.F., Slutsker, I., Tanré, D., Buis, J.P., Setzer, A., Vermote, E. Reagan, J.A., Kaufman, Y.J., Nakajima, T., Lavenu, F., Jankowiak, I., Smirnov, A. 1998. AERONET-A federated instrument network and data archive for aerosol characterization. Remote Sensing for the Environment 66, 1-16.

Institute for the Environment, 2009. SMOKE v2.6 User's Manual. University of North Carolina, Chapel Hill, NC. Available online at: http://www.smoke-model.org/ version $2.7 / \mathrm{html} / \mathrm{ch} 01 . \mathrm{html}$ (last visit: 30.01 .11 )

IPCC, 2007. Climate change 2007: the physical basis. In: Solomon, S., Qin, D., Manning, M., Chen, Z., Marquis, M., Averyt, K.B., Tignor, M., Miller, H.I. (Eds.), Contribution of the Working Group 1 to the Fourth Assessment Report of the Intergovernmental Panel on Climate Change. Cambridge University Press, Cambridge, United Kingdom.

Iversen, J.D., White, B.R., 1982. Saltation threshold on Earth, Mars, and Venus. Sedimentology 29, 111-119.

Kallos, G., Astitha, M., Katsafados, P., Spyrou, C., 2007. Long-range transport of anthropogenically and naturally produced PM in the Mediterranean and North Atlantic: current state of knowledge. Journal of Applied Climatology and Meteorology 46, 1230-1251.

Kanakidou, M., Mihalopoulos, N., Kindap, T., Im, U., Vrekoussis, M., Gerasopoulos, E., Dermitzaki, E., Unal, A., Kocak, M., Markakis, K., Melas, D., Kouvarakis, G., Youssef, A.F., Richter, A., Hatzianastassiou, N., Hilboll, A., Ebojie, F., Wittrock, F., von Savigny, C., Burrows, J.P., Landstaetter - Weissenmayer, A., Moubasher, H., 2011. Megacities as hot spots of air pollution in the East Mediterranean. Atmospheric Environment 45, 1223-1235.

Li, C., Hsu, N.C., Tsay, S.C., 2011. A study on the potential applications of satellite data in air quality monitoring and forecasting. Atmospheric Environment 45, 3663-3675.

Liu, Y, Sarnat, J.A., Kilaru, V Jacob, D. J, Koutrakis, P, 2005. Estimating ground-level PM2.5 in the Eastern United States using satellite remote sensing. Environmental Science and Technology 39, 3269-3278.

Malm, W.C., Sisler, J.F., Huffman, D., Eldred, R.A., Cahill, T.A., 1994. Spatial and seasonal trends in particle concentration and optical extinction in the United States. Journal of Geophysical Research 99, 1347-1370.

Marticorena, B., Bergametti, G., 1995. Modelling the atmospheric dust cycle: 1. Design of a soil-derived dust emission scheme. Journal of Geophysical Research $100,16415-16430$.

Menut, L., Chiapello, I., Moulin, C., 2009. Previsibility of mineral dust concentrations: the CHIMERE-DUST forecast during the first AMMA experiment dry season. Journal of Geophysical Research 114, D07202. http://dx.doi.org/10.1029/ $2008 J \mathrm{~J} 01052$.

Mitsakou, C., Kallos, G., Papantoniou, N., Spyrou, C., Solomos, S., Astitha, M. Housiadas, C., 2008. Saharan dust levels in Greece and received inhalation doses. Atmospheric Chemistry and Physics 8, 7181-7192.

MMA (Spanish Ministry of the Environment), 2010. CORINAIR Inventory of Emissions of Pollutants to the Atmosphere for Spain for Year 2007 (Prepared by AED for the General Directorate of Environmental Quality and Assessment).

MMA-CSIC (Spanish Ministry for the Environment - Superior Council of Scientific Research), 2007. CALIMA - Caracterización de aerosoles originados por intrusions de masas de aire africanas. www.calima.ws (last visit: 14.04.12)

Monks, P.S., Granier, C., Fuzzi, S., Stohl, A., Williams, M.L., Akimoto, H., Amann, M., Baklanov, A., Baltensperger, U., Bey, I., Blake, N., Blake, R.S., Carslaw, K. Cooper, O.R., Dentener, F., Fowler, D., Fragkou, E., Frost, G.J., Generoso, S., Ginoux, P., Grewe, V., Guenther, A., Hansson, H.C., Henne, S., Hjorth, J. Hofzumahaus, A., Huntrieser, H., Isaksen, I.S.A., Jenkin, M.E., Kaiser, J., 
Kanakidou, M., Klimont, Z., Kulmala, M., Laj, P., Lawrence, M.G., Lee, J.D., Liousse, $c$. Maione, M. McFiggans, $G$. Metzger, A. Mieville, A. Moussiopoulos, N., Orlando, J.J., O'Dowd, C.D., Palmer, P.l., Parrish, D.D. Petzold, A., Platt, U., Pöschl, U., Prévôt, A.S.H., Reeves, C.E., Reimann, S., Rudich, Y., Sellegri, K., Steinbrecher, R., Simpson, D., ten Brink, H., Theloke, J., van der Werf, G.R., Vautard, R., Vestreng, V., Vlachokostas, Ch., von Glasgow, R. 2009. Atmospheric composition change - global and regional air quality. Atmospheric Environment 43, 5268-5350.

Morris, R.E., Koo, B., Guenther, A., Yarwood, G., McNally, D., Tesche, T.W., Tonnesen, G., Boylan, J., Brewer, P., 2006. Model sensitivity evaluation for organic carbon using two multi-pollutant air quality models that simulate regional haze in the southeastern United States. Atmospheric Environment 40, 4960-4972.

NRL (Naval Research Laboratory/Monterey), 2010. Overview of NAAPS: Navy Aerosol Analysis and Prediction System. http://www.nrlmry.navy.mil/aerosol_web/ Docs/nrlmryonrprop.html (last visit: 26.04.12).

Onishi, K., Kurosaki, Y., Otani, S., Yoshida, A., Sugimoto, N., Kurozawa, Y., 2012. Atmospheric transport route determines components of Asian dust and health effects in Japan. Atmospheric Environment 49, 94-102.

Park, S.K., Cobb, C.E., Wade, K., Mulholland, J., Hu, Y., Russell, A.G., 2006. Uncertainty in air quality model evaluation for particulate matter due to spatial variations in pollutant concentrations. Atmospheric Environment 40, 563-573.

Park, R.S., Song, C.H., Han, K.M., Park, M.E., Lee, S.-S., Kim, S.-B., Shimizu, A. 2011. A study on the aerosol optical properties over East Asia using a combination of CMAQ-simulated aerosol properties and remote-sensing data via a data assimilation techn . Itmospheric Chemistry and Physics 11, $12275-12296$.

Pay, Jiménez-Guerrero, P., Jorba, O Baldasano, J.M., 2012. Spatio-tempc ation of particulate matter across $S$ mospheric Environment 46, 376-3s

Péré, J.-C., Pont, V., Mallet, M., Bessagnt centrations derived from satellite ol: South-Eastern France. Atmospheric

Pérez, C., Nickovic, S., Baldasano, J.M., ऽ 2006. A long Saharan dust event $o$ : photometer observations, and regic Research 111, D15214.

Prospero, J.M., Ginoux, P., Torres, O., N characterization of global sources o NIMBUS-7 TOMS Absorbing Aerosol Pro Viana, M., Mihalopoulos, N., Kallos, G., Kleanthous, S., 2009. African dust contributions to mean ambient PM10 mass-levels across the Mediterranean Basin. Atmospheric Environment 43, 4266-4277.

Rodríguez, S., Querol, X., Alastuey, A., Kallos, G., Kakaliagou, O., 2001. Saharan dust contributions to $\mathrm{PM}_{10}$ and TSP levels in Southern and E. Spain. Atmospheric Environment 35, 2433-2447.

Roy, B., Mathur, R., Gilliland, A.B., Howard, S.C., 2007. A comparison of CMAQ-based aerosol properties with IMPROVE, MODIS, and AERONET data. Journal of Geophysical Research 112, D14301. http://dx.doi.org/10.1029/2006JD008085.

Shao, Y., Wyrwoll, K.H., Chappell, A., Huang, J., Lin, Z., McTainsh, G.H., Mikami, M. Tanaka, T.Y., Wang, X., Yoon, S., 2011. Dust cycle: an emerging core theme in Earth system science. Aeolian Research 2, 181-204.

Shaw, P., 2008. Application of aerosol speciation data as an in situ dust proxy for validation of the Dust Regional Atmospheric Model (DREAM). Atmospheric Environment 42, 7304-7309.

Skamarock, W.C., Klemp, J.B., 2008. A time-split nonhydrostatic atmospheric model. Journal of Computational Physics 227, 3465-3485.

Taylor, K.E., 2001. Summarising multiple aspects of model performance in a single diagram. Journal of Geophysical Research 106, 7183-7192.

Tegen, I., Fung, 1., 1994. Modeling of mineral dust in the atmosphere: sources, transport, and optical thickness. Journal of Geophysical Research 99, 2289722914.

Thunis, P., Georgieva, E., Galmarini, S., 2011. A Procedure for Air Quality Models Benchmarking. Joint Research Centre (IRC), Ispra, pp. 20-25.

Torres, O., Tanskanen, A., Veiheiman, B., Ahn, C., Braak, R., Bhartia, P.K., Veefkind, P. Levelt, P., 2007. Aerosols and surface UV products from Ozone Monitoring Instrument observations: an overview, Journal of Geophysical Research 112, D24S47. http://dx.doi.org/10.1029/2007JD008809.

USEPA (United States Environmental Protection Agency), 2007. Guidance on the Use of Models and Other Analyses for Demonstrating Attainment of Air Quality Goals for Ozone, PM2.5 and Regional Haze. Office of Air Quality Planning and Standards, Research Triangle Park, NC. USA. EPA-454/B-07-002.

Vautard, R., Bessagnet, B., Chin, M., Menut, L., 2005. On the contribution of natura Aeolian sources to PM concentrations in Europe: testing hypotheses with a modeling approach. Atmospheric Environment 39, 3291-3303.

Vestreng, V., 2003. EMEP/MSC-W technical report. Review and revision. Emission data reported to CLRTAP. MSC-W Status Report 2003. EMEP/MSC-W note 1 2003. ISSN: 0804-2446.

Zender, C.S., Bian, H.S., Newman, D., 2003. Mineral Dust Entrainment and Deposition (DEAD) model: description and 1990s dust climatology. Journal of Geophysical Research-Atmospheres 108, 4416

Zhang, Y., Seigneur, C., Seinfeld, J.H., Jacobson, M., Clegg, S.L, Binkowski, F.S., 2000. A comparative review of inorganic aerosol thermodynamic equilibrium modules: differences, and their likely causes. Atmospheric Environment 34, 117-137. 